\title{
PRAVO NA SAMOODREĐENJE NARODA U SVJETLU MEĐUNARODNOPRAVNIH PITANJA I DISOLUCIJE SFRJ
}

\author{
Bartul Marušić \\ Hrvatski plemićki zbor, Zagreb
}

\section{Sažetak}

Pravo na samoodređenje naroda jedno je od najspornijih pojmova u međunarodnome javnom pravu. Jednako tako, taj je pojam ne samo pravni već i filozofski, politološki, sociološki i povlači za sobom razna pitanja i reperkusije. Zbog toga se njegovoj analizi treba pristupiti detaljno, postupno i interdisciplinarno kako bi se sagledali razni važni aspekti toga pojma koji dovode do odgovora na pitanje je li samoodređenje naroda princip ili pravo i koga se tiče, je li to pravo jus cogens de facto i de iure ili je uvjetovano i ograničeno drugim pravilima suvremenoga međunarodnopravog poretka. Tu se prije svega misli na kogentnu zabranu narušavanja teritorijalnoga integriteta postojećih država te ugrožavanja međunarodnoga mira i stabilnosti proklamiranih još u Povelji Ujedinjenih naroda. To povlači za sobom razmatranje načela uti possidetis i njegovih korijena i obveznosti primjene, jednako kao i secesije kao najčešće posljedice afirmativnoga ostvarivanja prava na samoodređenje naroda. Također se na to nadovezuje i pitanje disolucije država, najčešće federalnih, za koju se treba proanalizirati ima li ona materijalne razlike s obzirom na secesiju koja također nije izrijekom ni dopuštena ni zabranjena. Autor sve te povezane pojave i pojmove interpretira kroz nama najbliže poznat slučaj, i dalje nedavnoga, raspada bivše Jugoslavije koja je bila moderni presedan za federalne države, a ima odjeka i u aktualnim zbivanjima poput onih u Ukrajini i 
Španjolskoj. Da bi se imao još potpuniji dojam o povezanosti prava, politike i raznih interesa, progovara se i o konstitutivnosti naroda, manjinama i njihovim pravima na osnovi raznih dokumenata i mišljenja teoretičara te i o državotvornosti i državnom priznanju za koje jednako tako nema konsenzusa o tome je li ono konstitutivni ili deklaratorni akt trećih država i međunarodne zajednice. Da bi se izbjegao najgori mogući scenarij, a to je onaj prihvaćanja pravnoga „statusa quo“, treba kroz otvoreno raspravljanje i davanje prijedloga de lege ferenda precizirati pravnu problematiku kako se ne bi političkim i javnim diverzijama ili distrakcijama prikrivali interesi koji su ili suprotni duhu Ujedinjenih naroda ili su, s druge strane, legitimno suprotstavljeni jedni drugima.

Ključne riječi: pravo na samoodređenje naroda, raspad SFRJ, uti possidetis i secesija, politička filozofija

\section{Uvod}

Pravo na samoodređenje naroda najčešće je političkopravno „načelo“ na koje se narodi, odnosno političari, pozivaju prilikom velikih državotvornih promjena. Načelo uti possidetis je s druge strane imalo svoju prvenstvenu i preventivnu svrhu u priznavanju bivših administrativnih granica kao novih vanjskih državnih granica, ali, kako se i spočitava, to je vrijedilo prije svega za kolonijalne narode. ${ }^{[1]}$ Uti possidetis je načelo međunarodnoga prava na temelju kojega se unutrašnja razgraničenja između administrativnih jedinica priznaju kao državne granice $u$ trenutku stjecanja neovisnosti. To se načelo pojavilo u 19. stoljeću u procesu osamostavljivanja bivših latinskoameričkih kolonija. Pravo na samoodređenje jest pak ono koje se provlači i kroz kolonijalni ali i nacistički, komunistički i sav suvremeni javni kontekst. ${ }^{[2]} \mathrm{S}$ druge strane, problem i pravo samoodređenja o kojemu ćemo razlagati povlači za sobom i pitanje secesije kao njegova nužnoga korelata, posljedice ili

\footnotetext{
[1] U novije vrijeme prije Jugoslavije tim se načelom se rješavalo i pitanje Namibije, Zapadne Sahare i Istočnoga Timora, ali u drukčijem kontekstu. U postupku u vezi sa Zapadnom Saharom sudac je znamenito rekao kako ljudi trebaju odrediti sudbinu teritorija, a ne teritorij sudbinu ljudi.

[2] Predsjednik Churchill je pak isticao da se načelo (ili pravo?) samoodređenja ne primjenjuje (ni) na kolonijalne narode, nego samo na države pod nacističkom vlašću. Također je cijeli koncept upitno spojiv s pravilom zabrane jednostrane upotrebe sile, jednim od temeljnih u Povelji UN-a kao sljednice prijeratne organizacije Lige naroda. Vidjeti: Perišić, 2013, 763 i dalje.
} 
komponente. ${ }^{[3]}$ Kada se preklapaju teritorijalno i „personalno“ načelo, otvorena su slobodna vrata stvaranju državnosti, no, kada je jedno od toga drugačije ili se preklapa s političkim interesima velikih sila, jednako kao i s potencijalnim ugrožavanjem međunarodnoga mira i stabilnosti, tada nastaju ne samo faktični nego i pravni konflikti te su, kako kaže i Ibler, moguće zloupotrebe prava na samoodređenje. ${ }^{[4]}$ Ako uzmemo u obzir samo Europu i okolicu, problemi postoje ili mogu postati od Španjolske (Baskija, Katalonija...) i Velike Britanije (Sjeverna Irska, Wales, Škotska) pa sve do Francuske čak (Bretonci, Korzikanci) ili Italije (Venecija i druge državice) ili istočnih „zemalja“ koje su tradicionalno „bure baruta“ (istočna Ukrajina, $\mathrm{BiH}$, Kosovo i njegov sjever, kao i sjever i jug Makedonije, Vojvodina, Istra, Sandžak, Južna Osetija i Abhazija u Gruziji, Čečenija u Rusiji, Kurdistan itd.). Gotovo svaku od ovih potencijalnih secesija prati i pripajanje drugoj državi čineći od te iste „veliku“[5]. U radu se neće obrađivati takvi pojedinačni slučajevi, ali se mora upozoriti na sličnosti između problema i političkoga razmišljanja, jednako kao i na licemjernost velikih sila u njihovu postupanju. Jednako tako, načelo uti possidetis i pitanje secesije ili disolucije teme su za posebnu analizu, ali su neizbježni elementi reperkusije oko glavnoga pojma u ovome radu, a to je - samoodređenje naroda, i to napose u kontekstu mladih postjugoslavenskih država kao presedana $\mathrm{u}$ mnogočemu. ${ }^{[6]}$ Da bi se razumio pojam i samoodređenja i naroda, u svojim interdisciplinarnim, ali prije svega pravnim značenjima, potrebno je krenuti od početka.

\footnotetext{
[3] ICJ u svojem izvještaju iz 1986. napominje kako je načelo uti possidetis „kriterij“ za interpretaciju „principa“ samoodređenja. A taj je princip važan samo kada je država već postala neovisna, dok njezino širenje ili suzivanje počiva onda na drugim pravilima i načelima. Hadžić (2015) princip uti possidetis i pravo na samoopredjeljenje smatra potpuno različitima, a referendum izrazom „državotvorne volje“. Danas se sam uti possidetis načelno zasniva i na samoopredjeljenju i nemiješanju u unutarnje poslove, ali su u realnosti uvijek postojale borba i isključivost između „teritorijaliteta“ i „samoodređenja“. Ta je dilema jednostavno interpretirana načelom teritorijaliteta „kod kuće“, a kod drugih zemalja s „relativizmom“. Više: Christakis, 2015, 75.

[4] Zloupotreba prava na samoodređenje mogla bi dovesti do dojma da je teritorijalni integritet zemalja od sada "ugrožen“. U Nigeriji je npr. oko 250 jezičnih i etničkih skupina, a u Kamerunu 150. Tu je princip uti possidetis bio jedino moguće rješenje koje ne bi dovelo do kaosa i paradoksa načela prava na samoodređenje. Hannum, 1993, 27-30. [5] Srbiju, Hrvatsku, Albaniju, Bosnu, Sloveniju čak, Rusiju, Grčku, Italiju, Armeniju ili razne druge...

[6] Da taj presedan nema svoj temelj i budućnost u općim pravima secesije unutar općega međunarodnog prava (već je riječ o specifičnome slučaju) pišu A. Pellet i Radan te Petković, Raić i ostali.
} 


\section{Uti possidetis}

Definirani termin uti possidetis vuče svoje korijene iz rimskoga prava kao interdikt pretora kojim je branio uznemirivanje stanja posjeda koji je imao neki pojedinac i branio ga od drugoga pojedinca (uti possidetis ita possideatis). Pisci se nisu slagali oko toga je li tu riječ o zaštiti većega pravnog dobra ili o sprječavanju povrede mira (rule of peace koji je temelj svakoga mirovnog ugovora, ako nije suprotno eksplicirano). Međunarodna je stabilnost ,jedna od najšire uzetih koncepcija u diskursu samoodređenja“, kao i „princip teritorijalnog integriteta i restriktivne interpretacije samoodređenja" (Hasani, 2003, 30). ${ }^{[7]}$ Upravo i Povelja UN-a sve definira u kontekstu mira (ali i neintervencije, kao i teritorijalne cjelovitosti) te ga spominje više od 40 puta. ${ }^{[8]}$ Prema Niebuhru, izvor ovoga instituta treba pronaći u zaštiti okupatora javnih površina koji su, iako nemaju pravnu osnovu vlasništva, bili zaštićeni od uznemirivanja (J. B. Moore, 1913). ${ }^{[9]}$ $\mathrm{Tu}$ je svakako bila riječ još o privatnim osobama, ali posjed nije smio biti rezultat nasilja, odnosno vi, clam ili precaria nego u bona fide. Time su postavljeni budući temelji i privatnopravnih i javnopravnih načela, no još se dugo nije tu radilo o državama. Stariji autori poput Bluntschlia zamjerali su preslikavanje toga prije svega privatnopravnoga pojma i odnosa na međunarodni te jednako tako iziskivali razlikovanje statusa quo kao temporalnoga rješenja od konačnoga nedefiniranog statusa. U vezi s tim pitanje je i je li riječ o statusu quo ante bellum ili post bellum ili o obojemu kada je posrijedi rat. Termin je ipak najviše zamaha, i to prvi put u međunarodnome pravu, dobio pri definiranju granica današnje Južne ili Latinske Amerike. ${ }^{[10]} \mathrm{Na}$ dan neovisnosti o kolonijalnim gospodarima države su se trebale razgraničiti prema međusobnim bivšim „administrativnim“ granicama. Većina ih je to prihvatila svjesna opasnosti koju nude alternative

\footnotetext{
[7] Stabilnost Deutch i Singer definiraju kao vjerojatnost da sustav zadrži svoja obilježja, da nijedna nacija ne postane dominantna, da „ostane“ opstanak, a ne postane rat.

[8] Članci 1., 2., 11., 14., 15., 18., 23., 24., 26., 34., 39., 47., 50. - 54., 73., 76. i dalje.

Intervencija je, prema Walzeru, dopuštena upravo ako neka druga država to načelo zabrane intervencije već krši. Srbija je izbjegavala direktnu intervenciju u susjednim državama.

[9] Isti je autor skeptičan prema terminu uti possidetis juris jer je u obama slučajevima riječ zapravo o „faktičnom“ priznavanju stanja.

[10] No ni tu nije univerzalno uzet u obzir jer npr. ugovor Argentine i Paragvaja ne spominje uti possidetis ili posjed, za razliku od Argentine i Čilea (u svom čl. 34.). Kod Guatemale i Meksika „aktivan posjed“ uzima se pak kao „generalno pravilo“ (čl. 5.). U raznim drugim ugovorima posjedovanje se stavljalo u kontekst jednakosti i pravednosti.
} 
i povijesne spekulacije. ${ }^{[1]}$ Organizacija afričkoga jedinstva također je poticala rješavanje prema načelu uti possidetis i odbacivala svake druge etničke ili kulturne zahtjeve kao opasne za tako heterogeno stanovništvo afričkoga kontinenta. U Aziji je načelo samoodređenja (teritorijalnoga) i princip uti possidetis igrom slučaja bilo komplementarno, a ne u suprotnosti (umjesto da je tako općenito). To je zbog toga što je većina postkolonijalnih država samo vratila prijašnje granice za koje je već imala dugu tradiciju (osim problema ujedinjavanja država poput Koreja ili Vijetnama ili pak odvajanja Tibeta od Kine i slično). ${ }^{[12]}$ Također je u srednjem dijelu Azije stanovništvo „rijetko popunjeno“ i ondje je prošlo „bez puno pitanja želja malih populacija“ (Hasani 2003, 28). Uti possidetis kao princip od „rata“ značio je i da pobjednik zadržava teritorij, ali jednako tako, dok rat traje, on ima nad njim samo usufructus, te je novim mirovnim ili bilateralnim ugovorom moguće promijeniti taj titulus (Phillipson, 1916, 807). Uti possidetis se kao moderni pravni pojam prvi put „pojavio“ kod Richeliea (Ratner, 1996, 590-625). ${ }^{[13]}$

\section{Narod, nacija i država kao upitni elementi u pitanju samoodređenja}

Što uopće pravno i gramatički može značiti samoodređenje ${ }^{[14]}$ a što je uopće narod? Narod je skupina ljudi koju karakteriziraju vlastito ime, mitovi i povijesna sjećanja, razlikovni elementi kulture te povezanost i solidarnost. ${ }^{[15]}$ Nacija s druge strane u svojim integrativnim elementima i

[11] Lea Brilmayer većinu secesionističkih pokreta objašnjava upravo povijesnim spekulacijama ili uvredama (npr. Kosovo).

[12] Isto tako su i baltičke zemlje, nasilno anektirane od Sovjeta, samo povratile stari status i bile odmah priznate i od samog B. Jelcina.

[13] Ovaj pak autor uzima dakle kao dvopodjelu: uti possidetis juris i uti possidetis de facto. Pretorski edikt kod njega je činio upravo razliku sličnu današnjoj između posjeda i vlasništva (uti possidetis ita possideatis - „kako posjeduješ, tako posjeduj“).

[14] Patten (2015) razlikuje statističku, demokratsku i nacionalističku koncepciju samoodređenja. Dok prva pretpostavlja negativnu obvezu drugih da zadiru u unutarnja pitanja država, druga miče percepciju s država na ljude a treća se koncentrira na nacionalne socijalno-političke grupacije koje ne moraju biti ekvivalentne populaciji države. Dok jedna država može imati više nacionalnih grupa, dotle jedna nacionalna grupa može biti protegnuta kroz više država. Taj bi potonji princip ponajviše odgovarao separatističkim težnjama emancipacija manjina (kao „drugo“ samoodređenje nakon prvog raspada multinacionalnih država). Uistinu je snažan argument pitanje zašto bi jedna rijeka dijelila isti narod. Ali zato je, prema Lansingu, samoodređenje „fraza napunjena dinamitom“. Umjerena struja tvrdi da nema zahtjeva da svaka nacionalna grupa ima svoju državu, a isto tako negdje manjine nemaju čak niti vjerske ili jezične razlike (stečene nasilnim ili prirodnim putem), poput Škota ili Katalonaca.

[15] Prema ustavnoj ontologiji, narod se uglavnom shvaća kao zajednica onih koji zapravo dijele "politički eros“ i ljubav prema - naciji (!) a prema Paulu Kahnu, pojmovi naroda i narodne suverenosti stoje s one strane moralne argumentacije, a nacija i samoodređenje naroda nemaju svoje granice pa je vezanje teritorijalnosti s tim bespredmetno (?) Oklopčić, 2015, 7. 
stvaranju zajedničkoga identiteta ipak se oslanja na jedan administrativno zatvoreni teritorij. S narodom je povezan i pojam etnosa koji na grčkom također znači narod. No razlika je i među tim trima pojmovima, a kamoli još između svih tih triju i državljanstva, koje ne znači ništa drugo nego pravnu vezu pojedinca s dotičnom državom (kao superordiniranom pravnom osobom). Tijekom domaćih demokratskih promjena državljanstvo se slično kao i prije moglo zadržati kao „dvojno“, kako ono jugoslavensko, tako i (novo) hrvatsko. U bliskoj Bosni je, osim problema prihvaćanja „novoga“ državljanstva i nove države, također prisutan i problem faktičnoga nepostojanja nacije. Nacija bi trebala obuhvaćati sva tri konstitutivna naroda i usmjeriti svoje interese prema svojemu zajedničkom unutarnjem uređenju i samostalnosti. No zbog velike razlike u kulturno-povijesnome nasljeđu naroda te propaloj ideji jugoslavenske nacije kao i relativno novom uvođenju muslimanskoga (kasnije bošnjačkoga) nacionalnog identiteta, spomenuta država nije nikada kroz noviju povijest uspjela steći dovoljno vremena i volje, ni unutarnje ni vanjske, da stvori identitet koji će biti neovisan o susjednim državama i drugim silama (Hrvatskoj, Srbiji, Turskoj i raznim saveznicima). Jedini narod koji je državu htio autohtono definirati jest muslimanski, odnosno bošnjački. Njegovi su vođe htjeli državu stoga preurediti u građanski oblik kako bi opstala kao unitarna, iako su se odrekli ideje nacionalne države koja bi izazvala izravnu koliziju s drugima. ${ }^{[16]}$ Drugi su pak zagovarali ili sličan princip, u smislu konstitutivnosti naroda u svakome njezinu dijelu, ili kantoniziranje pa i podjelu države prema etničkim kriterijima koji su uvelike izmiješani. Jacobsen i Lipman (1946) pišu da su „država“ i „nacija“ opće shvaćeni kao sinonimi, čak u literaturi i u političkim znanostima, ali potonji pojam ipak sugerira dvije stvari političko i kulturno jedinstvo. Prva stvar obuhvaća vezivanje sve, ekonomski i kulturno, populacije koja okupira određeni teritorij i ima određenu vladu te uživa zajedničku suverenost. Ali kako to pomiriti s drugim uvjetom kulturnim jedinstvom koje ovisi o pojedinačnim populacijama i ponajviše njihovim tradicionalnim, lingvističkim, rasnim, vjerskim ili etničkim

\footnotetext{
[16] Makedonija se sama zbog istih razloga proglasila kao „građanska država“, ali je uspjela i opstati kao takva visa-vis kratkotrajnih nereda na sjeveru s etničkim Albancima nakon 2000. godine. Makedoniju su čak grčki premijer Mitsotakis i Milošević htjeli također podijeliti (Hasani, 2003, 215). Jednako tako nije tajna ni to da je Izetbegović nudio predsjedniku Tuđmanu (samo) Hercegovinu, kao ni činjenica da je hrvatski predsjednik i javno (u BBC-jevu dokumentarcu „Smrt Jugoslavije“ i „Slobodnoj Dalmaciji“ od 31/12/1991) rekao da je njegov politički stav u kriznim godinama rata bio podjela Bosne na tri dijela, odnosno tri države od kojih bi se srpski i hrvatski dio mogao pripojiti matičnim zemljama, a između bi ostala tampon državica.
} 
osobinama i povezanostima koje već tehnički čine pojam „nacije“ i nacionalnosti (Jacobsen, Lipman, 1946, 32)? Nju mogu činiti i većina i manjina populacije na određenome teritoriju i kulturne se razlike mogu prevladati u nacionalnome jedinstvu samo ako vlade ili političke frakcije ne zadiru u kulturne baštine ili ne čine subverzije u socijalnome poretku. Prema mnogim autorima, ekonomske su razlike, naravno, one koje čine (kao i 80-ih godina 20. st. u SFRJ) kulturne tenzije među stanovništvom, ali tvrde kako u današnje vrijeme grupacije ne mogu više mijenjati granice, pa čak i ako bi razlozi bili demonstrirani kao socijalno poželjni (Jacobsen, Lipman, 1946, 32-33). Pitanje kod nacije jesu i nacionalne manjine koje su „problem“ ako postaju destabilizirajući čimbenik pa Roger H. Soltaut (1951) ide čak dotle da kaže kako „ništa ne oslabljuje ljude (narod) toliko koliko nepomirljive manjine, bilo religijske bilo nacionalne... strani elementi kada odbijaju asimilaciju i inzistiraju na zadržavanju odvojenosti ne mogu se zadržavati u većem broju“ (H. Soltau, 1951, 30). Zadnji tu spomenuti pojam koji nije razbistren konsenzualno u znanosti i literaturi, a kamoli u općem žargonu, jest narod, odnosno ljudi (people). Budući da je već konstatirano kako narod i nacija nisu isto, činjenica je da je u međunarodnim izvorima i višestranim ugovorima rabljen pojam selfdetermination of peoples, odnosno samoodređenje „naroda“. Glavno pitanje, koje su već postavili mnogi autori, jest ono tko su ljudi, odnosno narod u pravnome smislu? ${ }^{[17]} \mathrm{Na}$ koga se to (sve) odnosi? ${ }^{[18]}$ Prije ulaženja u tu problematiku treba naglasiti problem tih pojmova ne samo pri prevođenju s jezika na jezik nego promotrimo razlike unutar samoga engleskog jezika. Oxfordov rječnik je pravno-politički pojam self-determination definirao kao pravo nacije (nation) da odredi svoju samostalnu politiku. ${ }^{[19]}$ Budući da je taj rječnik pojam samoodređenja nacije definirao tek na početku 20. st., nije uzeo tada u obzir činjenicu da je uskoro u donesenim deklaracijama

\footnotetext{
[17] Pitanje je i „tko“ su „samo“ (selves) u „samoodređenju“ i na kojem teritoriju. Mora li on biti striktno određen u administrativnim ili političkim granicama prema načelu uti possidetis? Većina teoretičara, pa i marksisti, uzimaju selves kao ono suprotno stranom (alien), odnosno suprotno vanjskoj dominaciji, što je ostao nedovoljno definiran problem u objektivnom i subjektivnom smislu. Prema Wilsonovoj maksimi (predsjednika T. W. Wilsona) „ljudi“ iliti people ne znače sva ljudska bića, nego samo „nezastupljene manjine“. O kojim je manjinama riječ i jesu li „manjine“ uopće manjine, problem je o kojemu se razlaže.

[18] Šućur (2014) prema Dugardu, prihvaća definiciju ljudi kao „manjine koja mora pokazati da zauzima određeni dio teritorija uspostavljene države u kojem formira čistu većinu“. Ta definicija itekako ide u prilog „manjinama“ kod samoodređenja, što je najdelikatnije za pojam naroda i teritorijalna jedinstva. Autor također ističe razliku između prava na samoodređenje kao reperkusije ljudskih prava i secesije koja je (iako vezana) predmet državnosti i državotvornosti. I manjine i secesije su nužni korelati problema samoodređenja, o čemu će se dalje govoriti.

[19] The Concise Oxford Dictionary of Current English fifth edition by Fowler, 1964, 1149.
} 
pojam zamijenjen, odnosno definiran kao samoodređenje - naroda, tj. ljudi (people). Razlika je velika ako uzmemo u obzir činjenicu da $\mathrm{u} \mathrm{BiH}$ ne bi bilo isto ima li pravo na samoodređenje (konsenzusom ili većinom; što je također prijeporno) cjelokupna bosanska nacija ili to pravo imaju i bosanski narodi od kojih su tri konstitutivna, a ukupno ih je mnogo više. ${ }^{[20]}$ O narodu se govori još u Bibliji. ${ }^{[21]}$ No pitanje samoodređenja počelo je zapravo još s Lenjinom u prvoj fazi koji ga je podvodio pod - naciju.

\section{Politička filozofija o pitanjima suverenosti, slobode i konflikta}

O pitanjima naroda, nacije i suverenosti te njihovim međusobnim odnosima, kao i o vlastitom pronalaženju emancipacije, pisalo se još od davnina. U staroj Grčkoj o tome je razlagao i Tukidid. On je iznosio cijeli proces, prema svojem viđenju, o tome kako teški politički konflikti pogoduju nastanku ratnoga ozračja „i tako postaju pravim uzrocima rata“. ${ }^{22]}$ Prema njemu, najistinitiji razlog za rat ostaje uistinu nevidljiv, ali on ipak nije ujedno i nešto „mračno, nerazgovijetno, nego tvori horizont unutar kojega kriza neizbježno poprima izgled ratnog uzroka“.[23] Politički konflikti nisu dakle uzroci rata sami u sebi, nego to postaju zbog povijesnoga stanja i razvoja nastanka država ili drugih grupacija. Napad Atenjana na Siciliju Tukidid shvaća oštrim pokušajem samoga osvajanja otoka, pri čemu su zaštita helenskih i ostalih naroda bili njihovo prividno savezništvo i samo izlika za rat koji nije izvirao iz „prisile nekog povijesnog stanja“, nego iz „volje za rat“.[24] Postoje uzrok, povod i izlika za rat, a svaki od tih ostaje upitan i za naše, suvremeno iskustvo. U kasnijoj su se znanosti samoodređenjem i inim pitanjima bavili već mnogi imanentni autori, poput Lockea koji je istraživao aspekt samoodređenja ljudi, ali u psihološkom i pojedinačnom kontekstu, pri čemu su se pojam i potreba za samoodređenjem povezivali s Bogom, krivnjom i slobodom. T. Hobbes je slobodu definirao negativno, dok je Berlin samoodređenje i samovlast

[20] Jedna od ideja je (bila) i postojanje bosanske narodnosti, što je najmanje ostvarivo zbog različitih vjera koje su se ispreplele sa nacionalnošću umjesto da su ostale kao drugi krak pruga koje se ne presijecaju, nego ostaju pravo izbora svakoga. (Vidi općenito o pokušaju uvođenja Hrvatske Pravoslavne Crkve)

[21] Biblija, Knjiga Postanka 12, 2-7., Kršćanska sadašnjost, 2005, 20.

„Velik ću narod od tebe učiniti... Tvome ću potomstvu dati ovu zemlju. “ Time od naroda Bog stvara naciju.

[22] Volkmann-Schluck, 1974, 18.

[23] Ibid.

[24] Ibid., 40. 
uzimao kao „pozitivan“ pojam. Ni Machiavelli nije zaobišao to pitanje, ali su se još u vrijeme njemačkoga idealizma o svim tim isprepletenim pitanjima bavili Kant i Hegel. Prema Kantu, i ustav je akt koji izvire iz jedinstva triju nabrojenih konstitutivnih principa: „slobode u smislu prava svakoga da oblikuje vlastiti život, jednakosti... i jedinstva volje... koja uključuje i nezavisnost“.[25] Ustav koji izvire iz ujedinjene narodne volje Kant naziva „prvobitnim ugovorom“ (contractus originarius). ${ }^{[26]}$ Taj je pojam Kant „preuzeo“ od Rousseaua, a sličan je i Hobbesovu pojmu „društvenog ugovora“. Državna zajednica, prema njemu, ne izvire iz životne nužde, nego je obratno. ${ }^{[27]}$ Državne vođe predstavlja kao „reprezentante narodne volje“ koji trebaju uživati poštovanje građana jer se njima povjerava teška zadaća zakonodavca i izvršitelja koji uvijek znaju što je dobro za zajednicu. ${ }^{[28]}$ Kant zbog toga poriče „pravo na otpor“, ali ne i kada je riječ o naredbama koje su „nemoralne“ ili krše ljudska prava. ${ }^{[29]}$ No, ako bi se pravo na otpor (jus resistendi kao npr. u Zlatnoj buli iz 1222.) izdignulo do „općeg načela“, time bi se potpuno dokinuo državni ustav. ${ }^{[30]}$ Skeptičan je i prema ustavnom dopuštanju otpora (neposluha) protiv vlade koja sama krši ustav jer bi time nastala „javna protuvlast“ i unijela pravnu nesigurnost. ${ }^{[31]} \mathrm{No}$, da je porijeklo demokracije revolucionarno, slaže se i Alexis de Tocqueville koji opisuje iduće: „Rado priznajem da je javni mir veliko dobro. Ipak, ne želim previdjeti da su svi narodi propali idući putem dobrog poretka

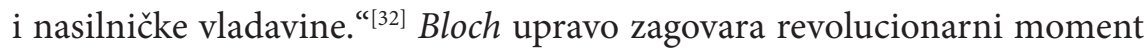
subjektivnoga prava kao takvoga. To je za njega „onaj momenat koji se ne pomiruje sa postojećim, nego mu navješćuje rat" (Pažanin, 1973). ${ }^{[33]}$ I to navješćuje „posebno postojećoj državi kao ujedinjujućoj normi objektivnog prava - sve dotle dok objektivno pravo s pomoću svoje posljednje norme,

[25] Ibid., 71.

[26] V: Ibid.

[27] Ibid., 74.

[28] Ibid, 75 .

[29] Ibid., 78-79. slično današnjim međunarodnoporavnim postulatima.

[30] Ibid., 79.

[31] Ibid. Nepravda se mora ,javno priopćiti državnim vlastima“, a upravo je sličnih „pritužbi“ bilo i u Banjoj Luci, a dolazile su od katoličkih svećenika, no na njih su se vlasti 90 -ih godina 20 . st. oglušile.

[32] Ibid., 121-123. Problem je i demokratske zloupotrebe njezinih vlastitih sredstava, poput tiska. Članak 3.1. UNESCO-ve Deklaracije o temeljnim načelima doprinosa sredstava javnoga priopćavanja učvrš́́enju mira.... „Sredstva javnog priopćavanja moraju imati važnu ulogu u jačanju mira i međunarodnog razumijevanja te u suzbijanju rasizma, aparthejda i poticanja rata", suprotno predrasudama, neznanju, neetici i sl. U Prijedoru je upravo medijska ratna propaganda bila „,bezočno lažna“, a u Višegradu je svjedok tvrdio kako su tenkovi izvana došli provocirati izgrede uoči bosanskog rata 1992.

[33] Pažanin 1973, 244. 
koja se zove solidarnost (Solidarität), ne osigura svakome - posljednje subjektivno pravo... “[34] J. S. Mill je bio utilitarist kao i Bentham (i „veći“), ali u načelu liberal. Stoga on kao i većina liberala tada propagira situaciju u kojoj što više individua može realizirati što više svojih „krajeva“ odnosno ciljeva, bez obzira na procjenu vrijednosti tih istih. ${ }^{[35]}$ I oni moraju biti sačuvani do mjere kada ne frustriraju svrhe, odnosno ciljeve ostalih. ${ }^{[36]}$ Liberali žele postaviti granice među pojedincima ili grupama ljudi samo u svrhu preveniranja kolizija među ljudskim namjerama koje sve moraju biti shvaćene jednako. ${ }^{[37]}$ Kant (koji je najbliži negativnom idealu slobode) i racionalisti ne žele gledati na sve svrhe jednako, nego samo racionalni ciljevi mogu biti pravi objekti stvarne prirode slobodnoga čovjeka. ${ }^{[38]}$ Hegel definira suverenost kao opću misao idealnosti koja egzistira samo kao subjektivnost koja je sigurna sama za sebe i kao apstraktno, te utoliko neosnovano, samoodređenje volje u kojemu se nalazi krajnja odluka. ${ }^{[39]}$ Država kao suverena treba biti jedan individuum (preko monarha). Običan čovjek vidi kako „monarh“ ima suverenu vlast i suverenost da čini što hoće, dok Hegel vidi suverenost države jedino kao monarha samog i kao nešto apstraktno, „te utoliko neosnovano“ spomenuto samoodređenje volje „u kojemu se nalazi krajnja odluka“.[40] Monarh je personificirani suverenitet (država to sam ja, za razliku od Lenjinova država to smo mi). ${ }^{[41]}$ Cijeli taj kontekst Hegelova tumačenja „suverenosti“ K. Marx kritizira u svojem osvrtu. Stoga je za njega trivijalnost Hegelov citat koji još kaže kako se „o narodnom suverenitetu može govoriti u tom smislu da je narod prema vani nešto samostalno i da tvori vlastitu državu“. ${ }^{[42]}$ Marx odgovara da, ako je vladar zbiljski suverenitet države, onda je on i prema van morao vrijediti kao „samostalna država“, čak i bez naroda. ${ }^{[43]}$ No, ako je suveren tako što reprezentira narodno jedinstvo, onda je on samo reprezentant i simbol

[34] Ibid.

[35] Berlin, 1958, 38.

Mill također tvrdi da je opći nužni uvjet slobodnih institucija (i opće sreće) to da granice vlada koincidiraju s nacionalnostima (Razmatranja o reprezentativnoj vlasti). A nacionalizam je jedna od "najpotentnijic“ stvari u modernome društvu ikad znana.

[36] Berlin, 1958, 38. To je i problem.

[37] Ibid.

[38] Ibid., 38-39.

[39] Glavni radovi Marxa i Engelsa 1978, 17.

[40] Ibid., 19.

[41] Ibid., 20.

[42] Ibid., 21.

[43] Ibid. 
suverenosti naroda. ${ }^{[4]}$ Država je apstraktum, a narod konkretum stoga se čudi što je apstraktumu dao „živo svojstvo“ kao suverenost. ${ }^{[45]}$ Također odbacuje Hegelovo bilo kakvo implicitno poimanje suprotne egzistencije suverenosti u narodu, a tautologijom naziva konstataciju kako je „narod bez monarha bezoblična masa bez ikakvih odredbi.....[46] Za Engelsa je sloboda nužnost, a ona je slijepa samo ako nije prepoznata.

\section{„Nacija“ u 20. st. i Lenjinizmu kao pravom političkom začetku samoodređenja naroda}

Velik broj autora unutar funkcionalizma naciju razumije kao „teritorijalno-državnu“ cjelinu, čime državljanstvo zapravo poistovjećuju s nacionalnošću (Lerotić, 1977). ${ }^{[47]}$ Prema njima se onda pripadnost naciji i sama nacija izvodi iz postojanja suverene državne vlasti. ${ }^{[48]}$ Etatisti pak naciju definiraju samo kao proizvod akcije koja je utemeljena na državi i prema cjelokupnome stanovništvu, dok je svaki ostali plemenski ili etnički pokret koji je usmjeren prema većoj autonomiji lokalni, regionalni ili komunalno-separatistički. ${ }^{[49]}$ Istraživanja su ipak pokazala da je empirijski nemoguće izjednačiti državu s nacijom, osim u nekoliko slučajeva kada je državni društveni poredak izjednačio sve pojedince, poput poznatih sjevernih zemalja (iako su se i mnoge među njima odvojile jedne od drugih) i koje čine tek oko $4 \%$ svjetskoga stanovništva. ${ }^{[50]} \mathrm{U}$ svim se ostalim zemljama integracija zasniva na zajedničkoj vlasti, a ne prošlosti, kulturi, vrijednosnim sustavima i sličnom. Na pitanje koji uvjeti moraju postojati da bi državna zajednica iz sebe podržavala danu državu, a da je ne dovedu u pitanje razlike i sporovi, odgovarali su funkcionalisti poput američkoga Talcotta Parsonsa. ${ }^{[51]}$ On upravo smatra kako je nedovoljno

\footnotetext{
[44] „Narodni suverenitet se ne izvodi iz njega, već obrnuto; njegov suverenitet postoji na osnovu suvereniteta naroda." Ibid.

[45] Ibid., 22.

[46] „U demokraciji se sam ustav pojavljuje samo kao jedna odredba, naime kao samoodređenje naroda. U monarhiji imamo narod ustava; u demokraciji ustav naroda." Ibid., 22-23.

Prema Hegelu je preobraćenje suvereniteta u monarha jedno samoodređenje volje, a o narodnoj se suverenosti govori u smislu da je jedan narod uopće prema van nešto samostalno i tvori jednu državu. Imaju svoje vladare i vlast i prema tome je, kako on smatra, onda narodna suverenost ujedno nacionalitet.

[47] Lerotić, 1977, 18.

[48] Ibid.

[49] Ibid.

[50] Ibid. 19.

[51] Više Ibid., 21.
} 
odrediti naciju državom - etatistički nego je, prema njemu, nacija socijalna zajednica koja čini središte solidarnosti i podlogu za društvenu integraciju (Parsons, 1967, 423). ${ }^{[52]}$ Budući da većina europskih nacija ipak ima etničku podlogu, ona je razumljivo snažna integrativna funkcija u državi. Iako suvremeno građansko društvo (napose VB i SAD), prema Parsonsu, oslobađa negativnosti koje pruža etnička struktura, ipak ona utječe na pojedinca „da je uzima kao ishodište vrednovanja drugih ljudi““[53] Rokkan pak nabraja sjeverne i zapadne zemlje koje su nastale također razdvajanjem zbog nemogućnosti homogeniziranja u jednu, dok one koje se nisu odvojile i dalje osjećaju duboke ožiljke (Škoti i Velšani, Baski i Katalonci, Bretonci i Korzikanci). ${ }^{[54]}$ Karl Deutch na pojam naroda (people) nadograđuje tri strukture: nacionalnost, naciju i nacionalnu državu, a samu nacionalnost definira kao „narod koji uporno nastoji postići djelotvornu vlast nad ponašanjem svojih članova“‘[55] „Nacija je već uspjela politička organizacija nacionalnosti, odnosno naroda, ona je politički narod, što znači da za njezin opstanak nije neophodno ozbiljenje državnog suvereniteta, već iznutra akumulirana i koncentrirana politička moć na bazi široke podrške većine naroda: ona je dakle, sprega narodne i na njoj izrasle političke zajednice. “[56] Izgradnjom samostalne države nacija ispunjava svoju funkciju na razini vlasti, a kad se narod konstituira kao nacija, on započinje unutrašnju samoizgradnju prema vrijednosnom ili moralnom uzoru. ${ }^{[57]}$ „Agresivni nacionalizam naciju uzdiže do paroksizma gdje individuumi moraju biti spremni na krajnju žrtvu... Spremnost na žrtvu vlastita života samouništenje individuuma za naciju - jest simbol nacionalne integracije... Preko smrti drugih nacija treba ići do ostvarenja ciljeva vlastite nacije.“[58] $\mathrm{Tu}$ je očito riječ o „agresivnom nacionalizmu“ koji je bliži „negativnom nacionalizmu“ kao šovinizmu, no i pozitivni nacionalizam postaje isključiv,

[52] Članak 1. hrvatskoga Ustava, kao i npr. članak 2. finskoga Ustava definira suverenost kao „vlast naroda“ (kao zajednice slobodnih i jednakih „građana“). Francuski ustav govori o vladi „ljudi, od ljudi i za ljude“. Hrvatski Ustav, osim o samoodređenju i suverenosti, govori i o nepovredivome pravu na odvajanje i udruživanje (ali ne više s jugoslavenskim zemljama). Udruživanje je kao samoodređenje prikazala i Rusija u referendumu kojim je Čečenija kao republika ostala u Ruskoj Federaciji 2003. No, ako se sjetimo Sporazuma iz St. Germaina, vidjet ćemo da Liga naroda tada nije dopuštala potencijalno ujedinjenje Austrije s Njemačkom bez suglasnosti Lige (to je dakako bilo prije nasilnog Anschlussa).

[53] Lerotić, 1977, 22.

[54] Ibid., 57.

[55] Ibid., 108-109.

[56] Ibid., 111. slično unutarnjem vidu prava na samoodređenje.

[57] Ibid., 112.

[58] Ibid., 115. 
i u teoriji agresivan, a u praksi katkada i šovinistički, kada ne može ostvariti svoje ciljeve i samosvrhu. F. Engels je isticao četiri komponente nacije: jezik, narodnost kao nacionalni osjećaj, teritorij i broj pripadnika nacije. ${ }^{[59]}$ Upravo on kao i Marx podcjenjuje pa i vrijeđa narode s Balkana, čime potiče i možebitne genocidne ideje (Watson) kroz nikad spominjani očiti politički delikt u svojim znanstvenim slobodama i radovima. Upravo te narode Engels ne zove nacijama stricto sensu, već nacionalnostima (možda tada još s razlogom). Time eksplicira tu pojmovnu razliku, ali isto tako uz takve narode pridodaje epitet „nepovijesnosti“, „kontrarevolucionarnosti“, „zaostalosti“, „nesposobnosti za vlastitu državu“, „denacionalizacije u korist velikih sila“ i slično. Te male nacije na Zapadu su Velšani, Baski, Bretonci, Kreoli, a na istoku dakle Hrvati, Srbi, Slovenci, ali i Bugari, Česi, Slovaci i dr. ${ }^{[60]}$ Umjesto prava na samoodređenje on njima predviđa i priželjkuje „uništenje“ i „apsorpciju u naprednije nacije“ kako bi i same tako napredovale. Bauer definira naciju ovako: „Nacija je narodna cjelina, ujedinjena zajedničkom sudbinom, koja posjeduje zajednički karakter. “[61]

Lenjin je među prvima povezao termin nacija (ne još narod) $s$ pravom na samoodređenje i njegovom realizacijom. ${ }^{[62]}$ Prema Lenjinu, nacionalna ideologija i nacionalni pokret istodobno su i građanska ideologija i građanski pokret. ${ }^{[63]}$ Nije se slagao s Buharinom koji je umjesto prava nacija na samoodređenje htio tada uvrstiti princip o pravu radnih klasa na samoodređenje. ${ }^{[64]}$ Lenjin se izrazio kako „svaka nacija ima pravo na samoodređenje do državnog odcjepljenja“.[65] Time je prvi put spojio i tezu i pravo o samoodređenju s pravom na odcjepljenje - secesijom. Značenje gesla pravo nacija na samoopredjeljenje ne izlazi iz okvira prava, tj. „apstraktnog i formalnog određenja ovog samoopredjeljenja, odnosno isključenja nejednakosti“.[66] Time bi se, prema njemu, riješilo zapravo

[59] Marx \& Engels 1967, 140.

Definicija uvelike podsjeća na onu Međunarodnoga suda o državi (state).

[60] Lerotić, 1977, 142 .

[61] Ibid., 169.

[62] Prema Ronenu (1979), ipak je i prije Lenjina, odnosno Marxa postojalo globalno, ali embrionalno samoodređenje, u obliku europskoga buđenja nacionalnoga pokreta sredinom 19. st. pa preko spomenutoga dvojca i njihova učenja, kroz kasnije nacističko i poslijenacističko vrijeme, završno s Wilsonovom politikom o manjinama i samoodređenju te raspadom komunističkoga bloka. Wilson je ipak bio u svemu tome protiv otvaranja antagonizama koji bi mogli narušiti mir Europe i posredno svijeta. Tu je taj sukob interesa.

[63] Lerotić, 1977, 194.

[64] Ibid., 196

[65] Ibid., 197.

[66] Ibid. 
nacionalno pitanje svuda gdje ono postoji. Proleteri su ipak neprijatelji svakoga nacionalizma (u buržujskome vidu) pa zahtijevaju "apstraktnu“ ravnopravnost kao isključenje svih privilegija i nejednakosti. U svojemu djelu O pravu nacije na samoodređenje polemizira s Rosom Luxembourg koja je protivnik glasovitoga paragrafa 9. iz 1903. koji unosi pravo na samoodređenje nacije. Ona znamenito iznosi tezu kako je baš najbolja nacionalna država „zemlja pljačkaša“ i puka apstrakcija jer svjetski ekonomski sustav zapravo priječi stvaranje samostalnih nacionalnih država. Iako je Lenjin naravno za to da socijaldemokracija isključuje bilo kakvo nasilje, ipak on pravo na samoodređenje drži u vidu „pozitivne norme“. No, iako Rosi prigovara da je strašljiva zbog svoje lokalne okoline, ipak se ,povlači“ implicitno tvrdnjom kako bi to sve bilo samo „eksperimentalno“ i kratkotrajno (de facto reverzibilno). Nacionalnost je, prema njemu, ipak „prirodno svojstvo“ koje ne određuje društvene podsustave i zato pripada području koje se može regulirati državnim i normativnim pravom i poretkom. Švicarsku daje za primjer najvećega nacionalnog mira dosljednim demokratizmom cijele države. Čak u buržoaskom nacionalizmu vidi demokratski sadržaj kada je riječ o borbi protiv „ugnjetavane“ nacije. I to podržava. Separacija (kao secesija) koja dovodi do stvaranja samostalne države može biti u interesu napretka nacije (obje). Marx je čak inzistirao na potrebi odvajanja Irske od Engleske. Spomenuta reverzibilnost postupka demokratizacije i osamostaljenja očituje se u Lenjinovoj ideji da se i sam ruski savez raspadne u manje države čiji cilj ne bi bio cjepkanje Rusije, već nakon toga ponovno ujedinjavanje, ali na ravnopravnoj bazi, i iz „zajedničkih simpatija“ prema radničkim i demokratskim interesima jednih i drugih. Ni demokraciju ni socijalizam Lenjin ne vidi kao prepreku, nego i nužnost da u temelju svega budu narod i njegovo odlučivanje o vlastitoj sudbini. Protiv je aneksije, no, ako bismo usporedili primjer kako je Bosnu anektirala Austro-Ugarska i Krim Rusija, vidjeli bismo da ni taj pojam nije bez problema. U prvome slučaju bilo je to protivno pravu na samoodređenje naroda, iako je Bosna tada živjela još najboljim životom, a u drugom je to u skladu s odlukom naroda na Krimu (barem u formalnome referendumskom pogledu). Potonje bi se moglo gledati i kao ujedinjenje, jednako kao npr. srpskih autonomnih oblasti (međusobno i) sa Srbijom, odnosno Saveznom Jugoslavijom, pa bi se to moglo gledati i s aspekta 
aneksije is aspekta ujedinjenja (para)država ako su međunarodno priznate, kao i s aspekta secesije od postojećih priznatih poredaka. U krajnjoj liniji, situaciju u Ukrajini ili Bosni neki bi mogli i htjeli tumačiti čak i kao raspad tih država. Zato je svaki pojam u međunarodnome pravu ključan za budućnost. I tijekom 90-ih godina 20. st. Srbija, odnosno SRJ, nije zato priznala nijednu srpsku oblast i pararepubliku (dok se same ne bi uspjele održati i izboriti za neki legitimitet ili uopće međusobno ujediniti za što su tek pripremale teren). I Hrvatsku je priznala (tek) nakon rata, pri čemu se čini da je pravo jačega bilo ključno mjerilo. ${ }^{[67]}$ Kako ne bi ispalo da je riječ o velikodržavlju, države izbjegavaju otvorenu politiku, katkada i na štetu onih kojima pomažu. A pomažu im uglavnom posredno i malokad vojnim prelaskom preko granice kako bi ostali u sferi legaliteta, i sve to dok pružaju ekonomske prilike ${ }^{[68]}$. Da se vratimo na Lenjina, on je iz mnogo manje perfidnih razloga bio deklarirano protiv ruskoga velikodržavlja, iako je očekivao zbiljsko ujedinjenje ponovno nakon raspada, a ne permanentni status. Legalnost ili protupravnost (a ne samo politička odbojnost) proširenja država drugo je pitanje... No, o pitanju prava na samoodređenje Lenjin zaključno čak pravi već i buduću distinkciju između unutarnjega i vanjskoga prava na samoodređenje. Pravo na samoodređenje, prema njemu, ide dublje jer ne traži samo demokratizaciju režima i političkoga poretka nego samu državnu zajednicu dovodi u pitanje, ali ako sve nacije jednako ne sudjeluju u vlasti, organima sile i svemu što je od opće važnosti za opstanak države. ${ }^{[69]}$

U prvoj je Jugoslaviji odnos u vlasti bio itekako jednostran ${ }^{[70]}$, unatoč tome što se ministarstvo poljoprivrede i potpredsjedništvo nudilo „HSS“-u, a u drugoj je, u vezi sa sudjelovanjem u organima sile, bilo tako da je u JNA bio zastupljen popriličan broj različitih narodnosti (od kojih mnogi nisu dali ostavke ni nakon 1992.). Ali to je bilo samo u njezinu vrhu.

[67] Secesionizam je bio stvar činjenice: ako su secesionističke snage bile kadre ostvariti novu državu, međunarodni je pravni sustav to zabilježio kao činjenicu postojanja novoga entiteta: Kohen, 2006, 5.

[68] U SRJ su se fondovi i novac koji su preneseni na strane račune istrošili, a inflacija u SAO Krajini, odnosno u „RSK“, dosegnula je i rekordnih $1000 \%$, unatoč medijskoj hvali tvornice „Tvik“. I Šešelj je govorio da bi strijeljao svakoga tko traži „srpsku armiju“ da dođe. Glede npr. tzv. Velike Srbije, malokad nakon Garašanina je bilo toliko otvorenih političara poput Šešelja ili Draškovića ili pak i Ćosića koji su je zagovarali. Dragan Vasiljković na aktualnome je suđenju govorio kako nije upoznao vojnika koji je bio za „veliku Srbiju“, iako su još 1990. na Kosovom polju ljudi vikali: „Ovo je Srbija.“ Također je i Karadžić u Haagu tvrdio da im nikada nije bila namjera Velika Srbija, a u intervjuu 1995. rekao je kako je cilj što brže ujedinjenje srpskih zemalja i kako sve republike trebaju imati zajednički parlament. A što je to nego upravo „velika Srbija“?

[69] Lerotić, 1977, 205.

[70] Vidjeti: Protega (2016), 133-149. 


\section{Psihologija masa i rata kao pretpostavka i posljedica „nasilnoga“ „samoodređenja“}

Poprilično reprezentativan sociolog glede problema rata i društvene anomije Karl Mannheim veže pojavu dezorganizacije, odnosno neurednosti društva, s neurednošću osobnosti. Upravo „zaplet ekonomskih, socijalnih i psiholoških faktora" te iracionalnost (ne samo neracionalnost) dovodi do općega zanošenja u rat i ponašanja masa (Mannheim 1960, 117). ${ }^{[71]}$ Većina pak ljudi na ulici odgovorit će kako je rat produkt „instinktivnog nasljeđa i nepromjenjive agresivnosti“.[72] Ali je zanos i psihologija masa (Le Bon), a ujedno i panika i sav paradoks bio vidljiv u sarajevskim demonstracijama 1992., kada su prosvjednici, usmjerujući negodovanje protiv svih vlasti i rata, prizivali „Tita“ i jugoslavenstvo te zaštitu JNA i Jugoslavije protiv koje su upravo potpisali referendum. Točno misli Manhheim kada s druge strane kaže da doista nema ništa u "takozvanom“ borbenom instinktu koji rat čini neizbježnim. ${ }^{[73]}$ „Njegovo postojanje samo objašnjava zašto, kada nas određene socijalne strukture predstavljaju u određenim situacijama, naša psihička 'oprema' čini nas borbenim... ili čak agresivnim. “[74] Jednom kada je socijalna struktura uređena tako da bi se mogao izbjeći rat, ona je tada kadra prevenirati formiranje ratnoga stava, i to prije svega preko kontrole edukacije. ${ }^{[75]}$ I prema Royceu postoji velika razlika između jednostavne i spontane mržnje i takozvane trenirane mržnje. U skupštini SR BiH ujesen 1991. predsjednik SDS-a upitao je vladajući SDA kako će spriječiti da „svak' svakog počne ubijati“ ako izbije rat. Kroz razne procese MKSJ vidljivo je da je anarhija obilježje stanja totalnoga rata, ali da i u njemu postoji vladajuća (politička ili vojna) (para)struktura koja ima moć i utjecaj te koja je u krajnjoj liniji propustila učiniti sve u njezinoj moći i dužnosti da zločin spriječi ili da ih naknadno kazni, što čini „legalizirajuću“ i poticajnu atmosferu za takvo što. ${ }^{[76]}$ Mannheim podsjeća kako ima mnogo nacija koje su živjele stotinama godina bez rata, poput Nizozemske (čiji su se UN-

\footnotetext{
[71] Mannheim, 1960, 117

[72] Ibid., 121.

[73] Ibid., 123

[74] Ibid.

[75] Ibid.

[76] O tome da država može katkada biti najveća opasnost za vlastito stanovništvo, kao i to da državna politika može biti poticajna i abolirajuća po stvaranju uvjeta za zločine (kao „nešto normalno i čak pozitivno“) vidjeti: Vajda, Namačinski, 2015, 142-185.
} 
ovi mirovni kontingenti u Bosni osjećali potpuno izbezumljeno i dobili čak PTSP od kojega su se liječili i navodno bili šikanirani pri povratku u domicilno društvo). „Mirno društvo, postajući nesigurno kao rezultat djelomičnog raspada, tako bolno prekida postavljena miroljubiva stajališta i teži ih zamijeniti društvenim ostatcima vojnih uzora koji još uvijek postoje u njima. “[77] On uspoređuje društvo sa pčelama i propituje u kojem je kontekstu opravdano ili neopravdano staviti ga u isti koncept zakonitosti sa životinjama. O simbolima (grbovi, zastave i sl.) jasno je da su to utopistički simboli koji potiču ljude na akciju, ali važna je bit problema. „Oni čine ljude da postupaju protiv sustava uspostavljenih veza i, radeći protiv njih, oni ne samo da pokušavaju slomiti mrežu tih veza nego traže dovođenje $u$ pitanje i prošle definicije situacije, devalvirajući značenje i značaj izvorne razine aspiracija. “[78] Kako nastavlja, društvo tada uskoro prelazi iz faze neorganizirane nesigurnosti $u$ "organiziranu nesigurnost“ jer uzroci nesklada u svojem funkcioniranju nisu maknuti, a strukturna nezaposlenost još postoji. ${ }^{[79]}$ Mogli bismo pod ovaj zajednički nazivnik staviti društva (napose $\mathrm{BiH}$ ) u vrijeme prijeratne Jugoslavije, a tako i društva poslijeratnih „samostalnih“ država. Spomenuli smo poznatu situaciju u skupštini BiH i proricanje istinite krvave budućnosti, no u takvim situacijama upravo vođama odgovara takvo stanje povlačenja mržnje preko psihologije masa. „Društvo postaje struktura gdje jedan pritisne gumb i očekivana reakcija krene. “[80] Upravo tako istim gumbom ona se i zaustavi. Jer, kako inače „jedna država može odlučiti da sa susjednom bude u nemiru, a zatim u prijateljstvu 10 godina"? ${ }^{[81]}$ Da se netko zasitio ili ne zasitio rata, nije baš to tako kada usporedimo npr. Daytonski mir nakon manje od četiri godine teškoga rata i stanje u Palestini i Izraelu koje traje (bar) desetljećima. Stvar je upravo „okidača“ koji negdje i dalje postoji i, čim ga se pokrene, usporedo sa strukturom poslušnosti, opet vodi u kaos. On se u takvim zajednicama može bilo kada upaliti i ugasiti. I Mannheim dalje naglašava psihološku razliku u neorganiziranoj i organiziranoj nesigurnosti. U potonjoj upravo „psihološka reakcija“ i „psihologija masa vlada svime“, a „kod posljednje se ima dojam kako su mase napustile svoj individualni psihički život, barem

\footnotetext{
[77] Mannheim, 1960, 128.

[78] Ibid, 133.

[79] Ibid., 135. „Što manje kruha, to više cirkusa.“

[80] Ibid., 137.

[81] Ibid.
} 
dok su javne afere uzete u obzir, i spremni su se pretvoriti u robote“.[82] Drugo je onda sociološko istraživanje „čudne psihologije“ vođa. „U prvoj fazi neorganizirane nesigurnosti ti vođe ne igraju vrlo važnu ulogu. “[83] $\mathrm{U}$ društvima masa nakon prve, spontane reakcije slijedi „manipulacija“. Max Weber opservira kako čak i u primitivnim društvima psihopatološki tipovi uglavnom postaju „spasioci“, „reformisti“ i mijenjaju stare načine života te razbijaju stara "magična stajališta“.[84] Upravo se „psihopati“ usuđuju slamati prošle navike (tako i sisteme). Poremećena osobnost, rekli bismo, prati poremećeno društvo umjesto da je korelacija balansirajuća. Rat, prema Mannheimu, nije zato produkt agresivnosti per se, nego „pogrešne elaboracije psiholoških tendencija kroz institucije, a djelomično i depresivnog zaleta ljudi u kolektivnu agresiju kada se nekoordinirane institucije sukobe i donesu osjećaj opće nesigurnosti“. ${ }^{[85]}$ Uza sve te akumulacije efekata ipak upravo „malo tko želi rat“.[86] Dok je Einstein još davno primijetio da ratove vode ljudi koji se ne poznaju zbog onih koji se poznaju a ne ratuju, Napoleon je još konstatirao i da u revoluciji i ratu postoje samo dvije vrste ljudi: oni koji ih dižu i oni koji se njima okoriste. Mannheim zaključuje kako nacionalistički slogani (u negativnome, ali možda i pozitivnome smislu) „zovu male ljude koji vole svoje domove i vrtove da postanu heroji ubijajući druge male ljude koji vole svoje domove i vrtove“. ${ }^{[87]}$

\section{Plebiscit (referendum) kao „instrument“ ili kao opravdanje narodne volje}

Činjenica je ipak da su svi referendumi u bivšoj Jugoslaviji koju analiziramo bili odlučeni uz većinu veću od $90 \%$ gotovo cjelovitih etničkih cjelina, kako hrvatskih građana, tako i srpskih u Hrvatskoj u vezi s osnivanjem autonomnih oblasti te jednako tako u Bosni i Hercegovini (a i u Donjecku, Luhansku i na Krimu danas). Nasuprot slovenskom, makedonskom i bošnjačkom izjašnjavanju, crnogorski su građani bili za

\footnotetext{
[82] Ibid.

[83] Ibid.

[84] Ibid.

[85] Ibid., 141.

[86] Ibid. Ponavlja čak dva puta.

[87] Ibid., 142.
} 
ostanak u Jugoslaviji (što znači i da nisu „svi“ dogovorili disoluciju). Jednako je tako odlučio srpski narod u Bosni i Hercegovini, dok je referendum o samostalnosti Bosne i Hercegovine bojkotirao (ali na "nagovor“ srpskih vlasti). ${ }^{[8]}$ Spomenimo i činjenicu da je isto tako i uz jednak postotak odbacio i mirovne planove poput Vance-Owenova ili onoga Kontaktne skupine. ${ }^{[89]}$ O tome da je multietnička država poput Bosne - protivna pravu na samoodređenje naroda (svih), govori Henry Kissinger koji sadašnji izborni sustav tamo naziva ruglom te zagovara ideju podjele i plebiscit u svakoj etničkoj regiji kao najbliži model američkomu povijesnom samoodređenju (Spajić, 2005, 119). Ali Bosna je rijetko gdje homogena (Hasani, 2003, 216). Nijedan ugovor u kontekstu samoodređenja naroda, a i izvan njega ne osvrće se na referendum ili plebiscit kao ikakav faktor ili instrument $\mathrm{u}$ vezi s tim pitanjem (Radan, 2002, 207). A referendumi su ono što svakako ne može izolirati do kraja poteze političara kao pojedinaca od poteza i odgovornosti naroda kao kolektiva. Radan tvrdi da su referendumi u Jugoslaviji bili protuustavni (zbog takve odluke Ustavnoga suda u Beogradu koja je sumnjiva i koju je nakon već slomljenoga ustavnog poretka donijela Miloševićeva vlast tijekom antibirokratske i antipokrajinske tzv. „jogurt“ revolucije). ${ }^{[90]}$ Također je pitanje, ako federalne jedinice kao republike nemaju pravo raspisivanja referenduma, tko ga onda ima, odnosno kako ga tek mogu imati pokrajine ili autonomne oblasti. Ipak, nije netočno kada Radan govori da su mnogi referendumi koncipirani „čudnim“ ili dvosmislenim indirektnim pitanjem, a, dodali bismo, politički čak pokatkad „kapcioznim“ ili sugestivnim. ${ }^{\left[{ }^{11}\right]}$ Kohen (2006) tvrdi kako je recentna praksa ustanovila da je referendum nužni uvjet za uspostavu nove države, iako

[88] I Armenija, Gruzija i Moldavija bojkotirale su referendum o ostanku u SSSR-u.

[89] Dostupno na: http://www.sudd.ch/event.php?lang=en\&id=ba011993 (10/4/2017.)

[90] I referendum o samostalnosti Katalonije španjolski Ustavni sud je ocijenio neustavnim.

[91] Prvo je pitanje glasilo (dostupno na wikipedia.org od NN 25/4/1991.)

„1. Jeste li za to da Republika Hrvatska kao suverena i samostalna država koja jamči... može stupiti u savez suverenih država s drugim republikama (prema prijedlogu $\mathrm{RH}$ i Slovenije...)? “ i

„2. Jeste li za to da Republika Hrvatska ostane u Jugoslaviji ... (prema prijedlogu RS i SRCG za rješenje državne krize u SFRJ)?“

Sam se referendum nazivao „referendumom za Hrvatsku“. Prvo se pitanje, međutim, odnosi na pitanje o konfederaciji država i eksplicitno se ne pita ni to želi li se i neovisna država per se niti želi li se konfederacija kao takva nego se implicira nekakav novi „savez“. Drugo se pitanje nadovezuje na ostanak Hrvatske u Jugoslaviji, kakav predlažu Srbija i Crna Gora, pri čemu se ne navodi nikakav tekst toga prijedloga za većinu populacije nepoznatoga (a kamoli njegovo objašnjenje). Također, Ustav RH donesen oko Božića 1990., prema čijim se člancima 87. i 98. raspisuje referendum, sam po sebi ispada neustavan ustavu države s kojom želi raskinuti odnose, a postavlja se kao da je suverenost već gotova stvar (što bi bio paradoks), i to prije i neovisno o referendumu. Jednako se tako više nije ni nazivala "socijalističkom“ republikom. Također, što bi bilo, recimo, da je na oba pitanja odgovoreno pozitivno? Budući da odgovori „moraju“ biti s „da“ ili "ne“, a ne pod a, b, c, onda bi to dovelo ne samo do paradoksa i vjerojatno poništenoga rezultata (ne i nevažećega) već i do očite dvosmislenosti i besmislenosti. 
to zapravo formalno nije. Imamo primjer Somailanda ${ }^{[92]}$, gdje je odluka građana bila afirmativna s više od $97 \%$, a secesija se ipak nije dogodila. Ta populacija građana nije navodno konstituirala „narod“ (people) koji bi učinio princip samoodređenja takvim da on federalne države pretvara $u$ konfederalne (?) Kohen 2006, 16. Referendum ipak nije ni uvjet ni razlog automatske secesije ali je veliki politički pokazatelj i demonstrator volje, za koju je upitno koliko je slobodna a koliko izmanipulirana.

Pri plebiscitu ili referendumu postoji i tzv. problem edukacije emocija (prema Mannheimu dalje). Od svih demokratskih institucija upravo je „plebiscitarni“ element u svojoj epohi najviše pridonio „destrukciji sistema“ (Mannheim, 1960, 356). ${ }^{[93]}$ I to nije novo, pa čak ni prijeporno, ali, iako je kruna demokracije i liberalizma te pravno-politički oslonac za odluke, plebiscitarni princip upravo vuče ljude "psihologiji masa“[94], a ne pojedinačnoj savjesti i svijesti. A psihologija masa je jedno od „jeftinih zla“ kojega se treba bojati i „litica ispred koje stoji demokracija“. ${ }^{95]}$ Upravo prema Mannheimu, mobilizacija cijele populacije za referendum (npr. za ostanak u Jugoslaviji, za osnivanje autonomnih oblasti, za raskidanje veza s njome, za bojkotiranjem referenduma, za prihvaćanje ili odbacivanje mirovnih prijedloga i sl.) u danim je okolnostima više „farsa“ nego neka prijelomna točka za nacionalnu budućnost. ${ }^{[96]}$ Prema spomenutome sociologu, referendum je razuman samo ako je primijenjen nad građanima malih zajednica. Promatrač (organizator) može tu samo mirno gledati „show“ masovnih emocija i biti potpuno neodgovoran, dapače, „nahraniti“ se legitimnošću koju mu referendum daje kao tobožnji indikator izravne volje i demokracije slobodnih „samosvjesnih“ građana. Međutim, u velikim zajednicama i državama plebiscit gubi svoju izvornu funkciju. ${ }^{[97]}$ Umjesto da se odnosi na pojedince koji žive u konkretnim grupama i sa svojim konkretnim problemima, on je adresiran na članove nedefinirane i emocionalne mase. ${ }^{[98]} \mathrm{A}$ „svrha demokracije nije igrati na emocije masa,

[92] Istočni, primorski dio u Afričkome rogu koji se htio osamostaliti od Somalije iste godine kada i Hrvatska is istom veličinom populacije (u svibnju 1991.; 4-4,5 milijuna).

[93] Mannheim, 1960, 356.

[94] Ibid.

[95] Ibid. Jednako tako, referendumi se ne raspisuju (od vlasti) u slučajevima kada im to politički ne odgovara, kao npr. za ulazak Hrvatske u NATO (tijekom pada popularnosti zbog rata u Iraku i opasnosti od fijaska).

[96] Ibid.

[97] Ibid., 357.

[98] Ibid. 
nego sprječavati nepostojane reakcije popularnih osjećaja od zatomljivanja racionalnih i razmotrenih opcija nacije“. Kada Radovan Karadžić „u ime srpskog naroda“ naglašava kako nije u redu od vladajuće bošnjačke stranke da tako podcjenjuje političku volju jednoga naroda koji želi ići svojim putem i u ime kojega ne smije odlučivati neki drugi narod snagom svoje brojčane populacije, ipak time postaje populist i demagog. „Vješta agitacija“ i „moćna propagandna mašina“, prema Mannheimu, anulira sadržajne rezultate referenduma i time pobija njegovu ulogu jer on više „ne interpretira opću volju“. Bitan je vremenski odmak, pri čemu svakako potpuna sloboda predizborne propagande „usmjerava“ volju birača koji kod referenduma imaju još najmanje izbora.

R. Karadžić je upravo imao argument kako spomenuti SDS „ne kreira“, nego „manifestira“ volju naroda i jedan je od najsnažnijih argumenata, ali tu su dva pitanja: koliki je (perfidan) utjecaj na volju građana da ona bude uopće slobodna i koliko ikakav politički utjecaj amnestira odgovornost odraslih razumnih pojedinaca pri biranju ${ }^{\text {?99] }}$ Prvi predsjednik RS-a u BiH također je isticao kako je vukao poteze kojima je izbjegavao rat. Je li to dokraja pogrešno ako uzmemo u obzir činjenicu da je upravo on potpisao Cutileirov predratni plan 1992., iz kojega se Izetbegović povukao (kao i iz Stoltenbergova), jednako kao i Vance-Owenov 1993. čiju je ratifikaciju pridržao za srpsku skupštinu (koja ga je ipak srušila) ili pak Filipović-Karadžić. Također je bespredmetno, ali ipak valja uzgredno spomenuti i političke sporazume s Matom Bobanom ili Fikretom Abdićem koji su, kako i kaže, uštedjeli nekoliko tisuća života u dolini Neretve i u Velikoj Kladuši. No, spomenuti sporazumi uvelike podsjećaju na MolotovRibbentropov pakt u koji nisu bili uključeni Poljaci (jednako kao ni ovdje Bošnjaci) ili na Pavelić-Stojadinovićev kojega je Tito proglasio „računom bez krčmara“. Unatoč tomu, i psihologija vođe kao pojedinca bila je također u ovome slučaju pod trostrukim pritiskom - od „naroda“ koji mu daje legitimitet, međunarodne zajednice i političkih istomišljenika o čijem aparatu također ovisi. Ipak, činjenica je da se uvelike planirano pristupalo ratu, kao i govorima biračima i narodu, unatoč kompleksnosti odnosa, jer je narod jedino mogao imati utjecaj na politička zbivanja, ali nije imao među

[99] Birajući antikomunističku koaliciju, mislili su da biraju „manje zlo“. Zanimljiv je bio i slogan te iste koalicije (HDZ - SDS - SDA, 1990.): „Bili smo i ostaćemo zajedno.“ 
tima nikako i vlast i moć koja je ipak u konačnici u rukama vođa. Ratni vođe „ovise“ o ratu i politički su ratni profiteri, dok je svakako zanemarena i „suodgovornost“ naroda za ratove. Ali oni mogu biti instrumentalizirani od elite (pa možda i nije toliko licemjerno bilo retoričko pitanje „ko nas, bre, zavadi“). Fašizam je najbolji pokazatelj manipulacija emocijama pa i uporabe demokratskih sredstava u nedemokratske i protuljudske svrhe.

Prema Mannheimu, stoga bi svakako pri referendumu trebalo odbaciti emocionalni element, ali ga snažno zadržati kod prethodne „reedukacije“ masa. ${ }^{[100]}$ I (jedino) tada bi trebalo, čak i snažno, „zaigrati“ na emocionalnu kartu, ali samo u svrhu reedukacije. To ne znači zato da je emocijama kraj, već se pažljivim rukovanjem njima ne bi ugrozile više vrijednosti uma: „njihova uloga u edukaciji masa utrla bi put razumnom rezoniranju“. [101] Ako bi obrazovne institucije bile koordinirane i planirane, one bi postupno napredovale od emocionalnoga stupnja do majstorstva emocijama. ${ }^{[102]}$ No, upozorava kako je takvo što moguće ipak samo u demokratskim državama, gdje dezintegracija grupa i njihova tradicionalnoga života nije otišla predaleko. Dok je u fašizmu duh propagande bio prožet u svim institucijama, u modernoj bi planiranoj demokraciji ${ }^{[103]}$ on trebao biti samo faza u hijerarhiji obrazovnih utjecaja. Cilj (propagande ili emocije) tada bi bio samo reorganizirati grupe i pojedince što je brže moguće pa makar i na najvišoj emocionalnoj uzvišenoj razini. ${ }^{[104]}$ „Jednom kada bi takva reedukacija bila provedena na širokoj sferi, plebiscit bi mogao ponovno imati realnu funkciju u demokratskom društvu. “[105] [106]

\footnotetext{
[100] Mannheim, 1960, 358

[101] Ibid.

[102] Ibid.

[103] U svojoj „britanskoj fazi“ Mannheim je zamišljao prijelaz s liberalnoga poretka laissez-faire kapitalizma, "osnovanog na slobodnom trgovinskom ciklusu, planskoj demokraciji, slobodnoj konkurenciji i idejama konkurentskog individualizma”, na planiranu demokraciju (ali ne „prerano“ da ne dovede opet do totalitarizma). U knjizi „Sloboda, moć i planiranje demokracije“ autor ne odriče nužnost planiranja kao ni problem društvene anomije i osobnih nepredvidivosti, ali prihvaća i razrađuje Goldhamerovu podjelu na „dominaciju i manipulaciju“ te Weberovu na „Zakonsku-racionalnu, tradicionalnu i karizmatičku“ formu legitimizacije. Kroz potonje Mannheim predviđa kriterije za „inteligentnu kontrolu predatorske vlasti“ i ne samo demokratizaciju mogućnosti obrazovanja nego i promjenu obrazovnih sadržaja koji bi ukazivali na stvarne raširene socijalne pojave i rješenja.

[104] Mannheim, 1960, 359.

[105] Ibid.

[106] Prema Crawfordu, plebiscit ima funkciju samo u određenoj granicama omeđenoj regiji, a ne za stvaranje novih entiteta (ili država). Vidjeti: Cassese, 1996.
} 


\section{Pravo na samoodređenje naroda kao pravno pitanje kroz razvoj međunarodnih ugovora}

Deklaracija o načelima međunarodnoga prava o prijateljskim odnosima i suradnji između država u skladu s Poveljom UN-a iz 1970. ${ }^{[107]}$ „najdetaljnije“ progovara o pravu na samoodređenje. U uvodu se već govori da se države (ne i narodi) moraju suzdržavati od prijetnje silom teritorijalnim integritetima i neovisnostima. A načela jednakih prava $\mathrm{i}$ samoodređenja važan su "doprinos suvremenom međunarodnom pravu“. Pravo na samoodređenje u dokumentima i u teoriji uvijek se „suprotstavlja“ načelu teritorijalnoga jedinstva i podređeno mu je te znači uvjetno pravo umjesto da je isključivo jer također spada u jus cogens. ${ }^{[108]}$ Budislav Vukas ${ }^{[109]}$ načelo ravnopravnosti i samoodređenja naroda također prepoznaje kao ius cogens, što je vidljivo iz dviju Deklaracija (o prijateljskim odnosima i suradnji među državama i Davanju nezavisnosti kolonijalnim zemljama i narodima $\left.{ }^{[110]}\right)$. Đura Minčić iz prve također iščitava i vanjski i unutarnji vid prava na samoodređenje kao „biranja putova svog ekonomskog i društveno-političkog razvitka“.[111] Prema predmetnoj (prvoj) deklaraciji, države ne smiju financirati i pomagati subverzivne i terorističke napade u (drugim) državama. ${ }^{[112]} \mathrm{O}$ „principu“ jednakih prava i samoodređenja ljudi (a ne još eksplicitno „prava“) uvodno stoji: SVI ljudi imaju pravo slobodno odlučiti, bez vanjskoga određivanja, o svojem političkom statusu i kulturnom te socijalnom i gospodarskom razvoju. ${ }^{[113]} \mathrm{Ne}$ definira ljude, ali ipak ističe da je riječ o „svima“. No odmah se u idućem odlomku osvrće i veže to pravo s procesom ubrzane dekolonizacije. ${ }^{[114]}$ Države moraju biti

[107] Rezolucija 2625 OS UN-a (rezolucije jednako tako nisu opinio juris).

[108] Higgins tvrdi da načelo uti possidetis nije ono kogentne naravi, za razliku i od samoodređenja i teritorijalnoga integriteta. Uti possidetis ne bi smio biti na štetu prava na samoodređenje, a sudac Abi-Saab znao je govoriti kako je načelo uti possidetis bilo uvijek interpretirano u svjetlu međunarodnoga pravnog poretka i zato nije apsolutno (Burkina Faso vs. Mali Frontier Dispute case). Vidjeti: Jankov, Ćorić, 2017. Dostupno na: http://www.esil-sedi.eu/fichiers/fr/ Agora_Fernandez_879.pdf (11/4/2017).

[109] U Zborniku Razvoj i perspektive Ujedinjenih naroda, 1973, 186.

[110] Rezolucija Opće skupštine 2621. (XXV) od 12.10. 1970. Ona tvrdi kako „svaki pokušaj da se djelomično ili potpuno razbije nacionalno jedinstvo i teritorijalna cjelovitost jedne zemlje nespojiv je s ciljevima i načelima Povelje Ujedinjenih naroda." Prema tome, i Jugoslavija, kao i mnoge multinacionalne države pod kapom ,jedne zajedničke nacije“ ne bi smjele podlijegati razbijanju cjelokupnosti.

[111] Zbornik Razvoj i perspektive Ujedinjenih naroda, 1973, 85

[112] Iako pomaganje (u granicama) nije načelno zabranjeno.

[113] Dok propisi proširuju ratione personae, praksa suzuje ekstenzivno tumačenje prema restriktivnom. Ipak, Federalna Njemačka ustvrdila je da je negeneralno tumačenje i limitiranje prava na samoodređenje protivno svakoj lingvističkoj interpretaciji: Centre for human rights 1987, UN sales No. E.87.XIV.2.

[114] Paradoks je da se i države stvorene dekolonizacijom prve opiru secesiji u svojim ustavima. Države koje i tvore međunarodni poredak ne bi dopustile njihovo komadanje, tvrdi Eastwood, 1993, 315. 
konstituirane upravo od volje ljudi (naroda) kroz implementiranje prava (tu kaže „prava“) na njihovo samoodređenje. Pred kraj naglašava da to pravo i ništa u ovim paragrafima ne smije biti konstruirano kao dozvoljavanje ili ohrabrivanje akcije koja bi narušila teritorijalni integritet, političko jedinstvo, suverenitet i neovisnost država. To bi bilo možda nespojivo sa smislom samoodređenja da se ta zaštita dakle ne uvjetuje (kao negativna pretpostavka prava na samoodređenje) time da se države ponašaju u skladu s gornjim pravima i prinicipima i da imaju vladu koja zastupa cijeli narod, odnosno sve ljude koji pripadaju određenom području bez razlike na rasu, vjeru ili boju kože. ${ }^{[15]}$ Taj je dio odredbe interpretiran kao unutarnje samoodređenje spram vanjskoga i, ako je on zadovoljen, onda priječi secesiju od neke države. ${ }^{[116]}$ Neki i samoodređenje dijele, osim unutarnjega i vanjskoga na - teritorijalno i etničko. ${ }^{[117]}$ Prvo je, prema Hasaniju, bilo baš provedeno u jugoslavenskim „sjevernim“ republikama Hrvatskoj i Sloveniji (Hasani, 2003, 201). Stoga je pozitivno pravo na samoodređenje izvedeno samo kao a contrario od negativnoga, ali nije razjašnjeno koja to država ne bi imala takvu vladu kakva se opisuje. ${ }^{[118]}$ U teoriji je takvih malo, i to onih nemudrih, ali u praksi to implicira jedino masovnu diskriminaciju, represiju i kršenje ljudskih i političkih prava (ali bez konkretnih mjerila). ${ }^{[119]}$

[115] Kako god se okrene pravo na „Vanjsko“ samoodređenje, koje je ipak okosnica, znači a priori ugrožavanje i negiranje teritorijalne cjelovitosti druge grupacije i njihove nove manjine. Također, priznavanje samoodređenja manjim narodima ugrožava i pravo na samoodređenje većim „nacionalnostima“ kao npr. Nigerijcima i Jugoslavenima! Također, nema ni garancije da te, „nove“ nacionalnosti neće ugrožavati manje druge, odnosno da „nove“ većine neće ugnjetavati (nove) manjine (Hannum, 1993, 41-64).

[116] Vidi: Cassese, 1995, 61 nadalje. Tako i Komisija za ljudska prava.

[117] „Iako prikazano kao pravo ljudi/naroda, samoodređenje je u stvari primijenjeno na određene teritorijalne jedinice...". I to prema Crawfordu na - nesamoupravna područja, države, odvojene političko-geografske entitete i „druge teritorije“. Također „paradoksno... samoodređenje je etnički osnovano i jako oslonjeno na etnicitet dok je konačna realizacija išla preko bivših administrativnih granica određenog tipa... stoga etničko samoodređenje se nije prepoznalo nakon Hladnog rata". Upravo je i Hrvatska, pozivajući se na samoodređenje i volju (naroda), zapravo prizivala i htjela teritorijalno, a ne narodnosno osamostaljenje u novu državu. Vidi: Hasani, 2003, 48.

[118] Uopće je prijeporno i koja država ne bi općenito imala: teritorij, stanovništvo i vladu (makar nasilnu).

[119] Vanjsko samoodređenje u tom se slučaju naziva izvanrednom „ljekovitom secesijom“ koja je jednako tako prijeporan pojam koji neki nazivaju i „kvalificiranom secesijom“, a neki poput Del Mara mitom jer secesija nije „lijek“ za kršenje temeljnih prava. Ista secesija predviđena je i Pariškom poveljom o jugoslavenskom pitanju. Manjine u novim državama očito ne bi imale pravo na odvajanje, ali bi, prema načelu prava na samoodređenje (a ne uti possidetis), bilo teško dokazati i kako su narodi u Jugoslaviji bili pod tolikom opresijom da je baš to bio povoljan moment za odcjepljivanje i separaciju ako ne raspad. Zna se da je glavni uzrok bila ekonomska kriza i devalvacija dinara 80ih godina 20. st. Nadalje, spomenuti prijedlog konfederacije, a ne potpuna osamostaljenja, mogao je biti motiviran isključivo decentralizacijom i postupnim raspadom, a ne ponovnim ujedinjenjem zbog nekakve jugoslavenske ideje ili Lenjinovih reintegrirajućih „uzajamnih simpatija“. Istina je i da sav onaj centralizam kakvom su republike u Jugoslaviji oponirale iste su sprovele u svojim državama (osim donekle Makedonije). Najgore je to ispalo u Bosni i Hercegovini. A srpski Memorandum politički je ravnopravnost republika predočivao kao problem i nepravdu veću nego princip „jedan čovjek jedan glas“ koji manifestira „jednakost“ građana, a ne nacija. No ta „jednakost“ upravo je davala mogućnost jednom narodu za „nadglasavanje“ te je i srpsko vodstvo bilo licemjerno kada mu taj model nije odgovarao u Bosni i Hercegovini i Hrvatskoj. Slična se pojava među Hrvatima u BiH naziva „majorizacijom Hrvata“ (u Federaciji $\mathrm{BiH})$. No, iako države ne bi imale pravo zastupanja prema van, ipak bi model potpune ravnopravnosti više nalikovao na konfederaciju u Jugoslaviji nego na federaciju. Međutim, ovako se povećao otpor ljudi koji je imao veće izglede za 
Možda će nam pomoći idući osvrt na manjine, ali i dalje nije jasno zašto jedno kogentno i temeljno pravo ne bi smjelo biti ostvarivo od političke volje koja ne mora biti samo rezultat nasilničke vladavine od druge. Imamo i više oblika nasilja, a i prividnoga nasilja ili propagande.

\section{Propisi o manjinama i drugi propisi o pravima na samoodređenje}

U Deklaraciji o pravima osoba koje pripadaju nacionalnim ili etničkim, vjerskim i jezičnim manjinama ${ }^{[120]}$ ne piše (za ni protiv) pravo manjinskoga naroda na samoodređenje ili bilo kakvu secesionističku i sličnu akciju. ${ }^{[121]}$ Uglavnom se prava svode na sudjelovanje u raznim javnim životima, pa i političkim (ali ne piše kako), te pravo na održanje svojega kulturnog, vjerskog i ostalog identiteta kroz jezik (opet ne piše u kojoj mjeri), vjerske i ostale aktivnosti kojima se povezuju i kontaktiraju s drugim manjinama ili onima kojima pripadaju u istoj ili susjednoj državi. No u čl. 4. (2) piše da nijedna praksa ne smije dovesti do nasilnoga ugrožavanja državnoga prava i postupanja protivno međunarodnim standardima. U čl. 8. (4) još se ta obveza, odnosno negativna pretpostavka potkrepljuje zabranom svake aktivnosti koja je protivna suverenoj jednakosti, teritorijalnom integritetu i političkoj neovisnosti država. No ključno je pitanje, koje nije opisano u međunarodnim dokumentima, tko proglašava neku zajednicu manjinom. U brojčanome smislu to je razumljivo unutar trenutne suverene države, ali u pravnome smislu i tijekom „nastajanja“ država to ne može biti ništa drugo doli tek jednostrani i „sigurnosni“ politički akt jedne države odnosno aktualne vlasti. ${ }^{[122]} \mathrm{O}$ manjinama i njihovim pravima piše slično i Pakt o građanskim i političkim pravima (čl. 27.), a i Međunarodna konvencija o ukidanju svih oblika rasne diskriminacije i

uspjeh u federalnoj nego u unitarnoj državi, a manje u federalnoj nego u konfederalnoj (iako u pozitivnome pravu kod secesije nema razlike između oblika država). A raspad države također ne bi smio imati bolje učinke od odluke samo pojedinih republika da istupe iz federacije ako se gleda pravednost.

[120] Rezolucija 47/135 OS UN-a od 18. veljače 1992., dostupno na http://www.un.org/documents/ga/res/47/a47r135. htm (7/4/2017), ali ni ona točno ne definira manjinu. Manjine su ionako per se marginalizirane u međunarodnim ljudskim pravima tvrdi Hannum $(1993,61)$.

[121] Ipak, u slučaju Aalandskih otoka (a i Zaira) rečeno je kako i manjine imaju pravo (ili bilo koji „ljudi“, tj. narodi) na samoodređenje kao ultima ratio (remedium) i iznimna solucija ako ne mogu ostvariti svoje ljudske (osobne $\mathrm{i}$ političke) slobode. Vidi: Marshall, 1921, 268-272.

[122] „Nove manjine su nastale (uhvaćene) ne zbog nekoga razumljivoga pravnog principa, nego zbog povijesne nesreće što su administrativne granice iscrtale neke (demokratske ili nedemokratske) vlade.“ Tako Hannum, 1993,56 (a slično je bilo i s Hrvatima u Jugoslaviji i Srbima u Hrvatskoj). 
njoj slične. Rimski statut u čl. 7. (1) govori kako je nasilno premještanje populacije (deportacija; pa i manjina) zločin protiv čovječnosti. Hrvatska je donijela Ustavni zakon o pravima nacionalnih manjina ${ }^{[123]}$ i tako ispunila nužne obveze EZ-a i poslije EU-a, a i UN-a. U njemu stoji sloboda izražavanja svake nacionalnosti i zabrana diskriminacije, kao i korištenje pismom i simbolima te pravo na obrazovanje na svome jeziku, a jednako tako i na samoorganiziranje, zastupljenost u predstavničkim tijelima $\mathrm{u}$ određenome broju, sudjelovanje u javnome životu itd. Nacionalna je manjina definirana kao: „skupina hrvatskih državljana čiji pripadnici su tradicionalno nastanjeni na teritoriju Republike Hrvatske, a njeni članovi imaju etnička, jezična, kulturna i/ili vjerska obilježja različita od drugih građana i vodi ih želja za očuvanjem tih obilježja“ (čl. 5.). Članak 40. opet regulira ograničenje od svakoga ugrožavanja cjelovitosti, jedinstvenosti i neovisnosti Republike Hrvatske, kao i poštovanje međunarodnoga prava. Sličan analogni zakon koji je vrijedio i u SRJ ${ }^{[124]}$ definirao je manjine uz razlikovne elemente i po brojčanome parametru prema većini. Njegov čl. 7. jednako tako sadržava spomenuta tipična ograničenja prava. Međutim, ne određuje broj zastupnika u organu državne vlasti. Pravilo da se manjine ne smiju odvajati od države u kojoj žive proklamirano je zapravo i u Povelji UN-a (Perišić, 2013, 764), ali uz bok zabrani (tada još uvijek) potpunoga osamostaljenja od kolonijalnih vladara, kao i spajanje nacija iz više država u jednu. Pitanje „samoodređenja manjina“ izjednačeno je i sa konstitutivnim narodima koji tvore višenacionalnu državu poput $\mathrm{BiH}$ ili Švicarske, a postavlja se pitanje kako se više jednakih ili različitih nacija može ujediniti onda u federalne države poput SFRJ? ${ }^{[125]}$ I drugo je pitanje, ako zaključimo da $\mathrm{BiH}$ nije "Jugoslavija u malom“ samo zbog toga što nije ista „vrsta“ federacije, bi li se Švicarskoj Konfederaciji (koja je u svojoj biti federacija) priznale administrativne granice između kantona kao nove, vanjske? Ni diskontinuitet jednoga entiteta (ili države) nije nemoguć kada se granice usporede s već postojećim dvjema oblastima njemačke zajednice u istočnoj Belgiji (koje imaju prava slična planu „Z4“) ili raznim oceanskim otocima. A i Federacija BiH kao svaka federacija imala bi se onda pravo

[123] Ustavni zakon o pravima nacionalnih manjina, zadnje NN 93/11.

[124] Zakon o zaštiti prava i sloboda nacionalnih manjina („Sl. list SRJ“, br. 11/2002, „Sl. list SCG“, br. 1/2003. -

Ustavna povelja i „Sl. glasnik RS“, br. 72/2009. - dr. zakon i 97/2013. - odluka US-a).

[125] Ujedinjenje je isto tako samoodređenje, ali je pitanje koliko je bilo „dobrovoljno“. 
i raspasti samo s upitnim razgraničenjima. Načelo jednakosti upravo bi trebalo značiti isti princip za sve narode i države, a također vidimo i da se kriteriji Povelje mijenjaju tijekom godina pa ne treba odbaciti ni mogućnost da se manjinama s vremenom dopusti „pravo“ na secesiju, ali politički je to daleko. Jednako tako ne vidi se drugi razlog da se i teoriju geografske distinkcije koja daje pravo samo tim određenim narodima na totalnu samoupravu (tzv. slanovodna teorija) ne zamijeni i kontinentalnim vidom (tzv. slatkovodna teorija).

U Deklaraciji o pravu na razvoj ${ }^{[126]}$ u čl. 1. (2) stoji kako ljudska prava također podrazumijevaju puno ostvarenje prava na samoodređenje, što i, prema obama paktovima o ljudskim pravima, uključuje primjenu neotudivoga prava naroda na punu suverenost nad svojim bogatstvima. A već se u preambuli podsjeća na pravo naroda na samoodređenje, prema kojemu oni imaju pravo slobodno određivati svoj politički status i osigurati svoj gospodarski, društveni i kulturni razvoj. Članak 5. potiče i obvezuje države na „odlučne korake protiv odbijanja prava na samoodređenje“.

Bečka deklaracija iz 1993. ${ }^{[127]}$ u čl. 2. piše kako „svi narodi“ imaju pravo na samoodređenje. Biraju svoj politički i gospodarski status, a uz kolonijalnu prepoznaju se i „drugi oblici strane dominacije ili okupacije“. Pravo na samoodređenje definira se kao „neotuđivo“ i ljudsko pravo ( $a$ contrario prema tome da su njegova kršenja - „kršenja ljudskih prava“). ${ }^{[128]}$ [129] Ponovno se ističe da ono ne opravdava povredu teritorijalnoga i političkoga integriteta i jedinstva, ako vlada u toj zemlji predstavlja, bez razlika, cijeli narod koji obitava u njoj i općenito ako poštuje načelo jednakih prava i prava na samoodređenje naroda. ${ }^{[130]}$ Kao prvo, u jednoj

[126] Rezolucija br. 41/128 OSUN od 4. 12. 1986. Rezolucija pak 637 (VII) A u prvome stavku naglašava da se države UN-a trebaju držati „principa“ samoodređenja SVIH naroda i „nacija“. U drugome stavku nastavlja, ali nevezano, obvezu ostvarivanja narodne volje (preko plebiscita i drugih demokratskih oblika) u nesamoupravnim područjima i „trustovima“. Dostupna na: www.nationalunitygovernment.org $>$ pdf-doc (10/4/2017)

[127] Bečka deklaracija i program djelovanja, usvojena na Svjetskoj konferenciji o ljudskim pravima 14. - 25. lipnja 1993. i potvrđena na 48. zasjedanju OUN-a kao rezolucija 48/121., ali koja zbog svoje nesveopće prepoznatosti još uvijek ne znači također čvrsti opinio juris.

[128] Je li pravo na samoodređenje samo širi pojam prema užemu s obzirom na ljudska prava, je li njihov ,jamac“ ili je to pravo kompenzirano nekim drugim pravom, nije sigurno.

[129] Prema Araujo $(2001,1492)$, samoodređenje služi kao garant temeljnim ljudskim pravima. Mnoga su prava su derogabilna (život, iskazivanje vjeroispovijesti...) pa se tako može poopćiti i na pravo na samoodređenje (u čl. 4. MPGPP-a države mogu nediskriminatorno derogirati obveze iz tog pakta pa i samoodređenje sukladno tomu).

Prema Hannumu $(1993,61)$, zajednice koje traže pravo na samoodređenje uglavnom se i ne zadovoljavaju, kao što i vidimo, (formalnim ili čak stvarnim) jamstvom „običnih“ ljudskih prava.

[130] I Islamska deklaracija Alije Izetbegovića nije bila uopće suprotna tim tendencijama ni radikalna kako se spočitava. Jedini je uvijek odnos pri tome - tko je većina, a tko manjina. A manjinama se uvijek garantiraju sve slobode i jednakosti vjere, jezika i identiteta. Dostupno na: http://www.vakat.me/wp-content/uploads/2017/01/ Islamska-Deklaracija-knjiga-o-islamizaciji-muslimana-Alija-Izetbegovic.pdf (8/4/2017). Kako sugerira i naslov, riječ je 
državi ne mora obitavati jedan narod, a ako više njih želi različito urediti državu bez obzira ili s obzirom na brojčanost, onda je završni dio rečenice i odredbe očiti contradictio in adjecto i dvosmislenost koja je u pravu katkada opasnija nego da se nešto uopće ne definira. UN-ova deklaracija o pravima autohtonih naroda iz 2007. (61/295) u čl. 3. takvim narodima propisuje pravo na samoodređenje, a poslije navodi njihova prava na kulturno i institucionalno organiziranje (ali) unutar država. A članak 46. tipično štiti pravo teritorijalnoga integriteta.

Završni akt konferencije o sigurnosti i suradnji u Europi iz Helsinkija 1975. ${ }^{[131]}$ koji je potpisala i Jugoslavija (na zadnjem mjestu) nameće državama obveze suzdržavanja od svakoga nasilja i poštovanje teritorijalnoga integriteta i jednakosti. Granice se smiju mijenjati samo miroljubivim načinom i sporazumno (I., III., IV.). Manjine i njihova prava (pojedinaca) trebaju se poštovati u državama u kojima žive. U VIII. poglavlju normiraju se pravo na jednakost i samoodređenje i taj se „princip“ ne smije povrijediti (ius cogens), ali opet je uvjetovan radnjama u skladu s međunarodnim pravom jedinstvenosti. No, u drugome stavku piše da pravo na samoodređenje imaju SVI ljudi/narodi UVIJEK i u PUNOJ slobodi, KADA i KAKO to žele, te mogu urediti svoj UNUTARNJI i VANJSKI politički status, BEZ vanjske intervencije i odrediti svoj politički, ekonomski, socijalni i kulturni razvoj. Tu se ne eksplicira da se odnosi samo na kolonijalne države i nesamoupravna područja, ali, ako se ne misli samo na vanjsku intervenciju prema drugim državama, onda ovo opet teritorijalno uvjetovano ograničenje prava na samoodređenje opet nema smisla jer u današnje vrijeme u ovoj ili onoj formi nema više zapravo terra nullius ili država koje nisu suvereno uređene ili priznate kao takve. To bi se analogno moglo usporediti s pravom na slobodu zatvorenika pod uvjetom da ne iziđe iz zatvora.

Dok Europska konvencija o ljudskim pravima ne progovara o pravu na samoodređenje, Afrička povelja o ljudskim pravima iz 1981. ima nekoliko odredbi. ${ }^{[132]} \mathrm{U}$ čl. 20. nameće se pravo na egzistenciju i neporecivo i neotuđivo pravo na samoopredjeljenje naroda da slobodno odlučuju

o islamizaciji muslimana, a ne svekolikoga stanovništva. To je bila i borba protiv ateizma i komunizma.

[131] Dostupan na: www.osce.org/helsinki-final-act?download=true (8/4/2017)

[132] Dostupna na: http://www.humanrights.se/wp-content/uploads/2012/01/African-Charter-on-Human-and-PeoplesRights.pdf(9/4/2017) 
o svojim statusima i oblikuju svoj razvoj u skladu s politikom koju su izabrali. Uz prava na progresivni mir, život i obitelj, u čl. 25. govori se o tome da suverenost počiva na narodu i da nijedan dio naroda ne smije odlučiti umjesto cijeloga (tu se misli i na pitanje rasne manjine kao za vladavine u JAR-u ili Južnoj Rodeziji $\left.{ }^{[133]}\right)$. Američka konvencija o ljudskim pravima ne definira i ne spominje samoodređenje, ali osigurava „pravo na nacionalnost“ (čl. 20.) i „sudjelovanje u vlasti“ (čl. 23.). ${ }^{[134]}$

Međunarodni pakt o građanskim i političkim pravima ${ }^{[135]}$ već u I. dijelu i 1. članku proklamira "pravo na samoodređenje“ i na temelju njega određivanje svojega slobodnoga političkog statusa i razvoja (u skladu s Poveljom).

\section{Priznanje država}

Uzima se načelno da je priznanje država samo deklaracija postojećega stanja. ${ }^{[136]}$ Ako priznanje ne bi bilo samo deklarativno, upitan je npr. i kontinuitet Republike Bosne i Hercegovine s BiH prema Aneksu 4. Općeg okvirnog sporazuma. A i Savezna Republika Jugoslavija u političkome je smislu iziskivala da bude (jedina) sljednica SFRJ pa nije ni tražila priznanje, dok je, glede ratnih zločina, dizala ruke od bilo kakve izravne pravne veze s činjenjima vojski SFRJ i SRJ. Da bi države bile kadre ući u diplomatske i ostale odnose s drugima, ipak im je priznanje nužno (Šućur, 2014, 283). Pa „iako pravo države da se tretira kao takva ne ovisi o priznanju, priznanje država ipak je nužan dokaz da je pravo ostvareno“ (Hall, 1890, 87). ${ }^{[137]}$ Raspravlja se u teoriji i o tome ima li razlike između priznanja države prednice i ostalih trećih država, pri čemu, osim očitoga sprječavanja sukoba, nema zapravo razlike u pravnoj snazi. Dapače, može doći i do „preuranjenog priznanja“. Jednako tako, definitivna

[133] Ian Smith, bijelac, koji nije mogao biti reprezent cijele narodne volje, proglasio je 1965. jednostrano samostalnost od Ujedinjenoga Kraljevstva. Sličan je problem i kod Bantustana ili TNC-a zbog kršenja jus cogensa od strane njihove vlastite vlade.

[134] Dostupna na: http://www.oas.org/dil/treaties_b-32_american_convention_on_human_rights.pdf (9/4/2017)

[135] Usvojen u Općoj skupštini Ujedinjenih naroda 16. 12. 1966. kao Rezolucija br. 2200 A/XXI.

[136] Republiku Hrvatsku nije dosada priznalo i stupilo s njom u diplomatske odnose 15-ak država. One dakako nisu odgovorile ni na upit o tome zašto nisu (upućeno njihovim ministarstvima vanjskih poslova za potrebe ovoga rada). Zanimljivo je spomenuti da upravo Sveti Kristofor nije priznao Hrvatsku, a njegov ustav (kao i etiopski iz 1994.) dopušta neke oblike secesionističkih aspiracija. Možda je upravo to bio razlog nepriznavanja Hrvatske (spram njezina odnosa prema „RSK“ zapravo, a ne Jugoslaviji).

[137] Isti autor koji je izdavao tekstove upravo u vrijeme priznanja „Servie“ i Rumunjske, ali i Belgije i Grčke, za te je države pisao kako su nastale „intervencijom“ (radi rješavanja političkih pitanja), a ne pravim priznanjem. 
samostalnost i osnova za legitimno priznanje bit će tek kada država koja pretendira na teritorij koji se osamostaljuje, odnosno matična zemlja, ne bude više mogla nad drugom uspostaviti ponovni autoritet borbom, a ne tek samo formalnom pretenzijom (Hall, 1890, 93). „Tradicionalni pogled da je priznanje deklarativnog, a ne konstitutivnog efekta treba revidirati.“ (Kohen, 2006, 12). Nemogućnost uspostave ponovne vlasti mora biti „izvan svake razumne sumnje" (Christakis, 2015, 95). Kohen, prema Tancrediju, izvodi tri pretpostavke da bi secesija mogla dovesti do stvaranja države: a) odsutnost svake strane intervencije ${ }^{[138]}$ (za razliku, recimo, od Krima), b) odluka većine populacije referendumom, c) poštovanje principa uti possidetis (Kohen, 2006, 14). U suprotnome, nepriznanje od trećih država nije razlog nepostojanja državnosti, koliko god ona imala snažne efektivne elemente, nego je ono rezultat ipso facto kršenja peremptornih pravnih normi od strane tražiteljice. Države nemaju ipak obvezu priznati državu (i secesionistički pokret), ali u određenim situacijama (kršenja međunarodnoga prava) imaju je obvezu "ne priznati“ (Christakis 2015, 96). Konvencija iz Montevidea naglašava kako su države nakon ispunjenja pretpostavki ipak „dužne“ odobriti priznanje. Prema konstitutivnome pogledu, država koja nema apsolutno priznanje država u svijetu (pa tako i Hrvatska) istodobno je onda i „država“ $i$,nedržava“, $i$ to ne samo prema njima nego i erga omnes. Lauterpacht priznanje država ionako naziva „grotesknim spektaklom“ (Lauterpacht, 1947), a mnoge države koje su faktično ispunjavale uvjete za priznanje ipak ga politički nisu dobile (Turska republika Sjeverni Cipar, Bantustan, J. Osetija) jer ako države nemaju i kapacitet da uđu u odnose s drugim državama, onda su one kao an inanis speculo, dok su ga one koje to još nisu ispunjavale dobile iz političkih razloga (kao Panama).

\section{Secesija, konstitutivnost i ustavnost}

Međunarodno je pravo neutralno prema secesiji i čak je ne zabranjuje, što znači da etnički princip samoodređenja nije protupravan i to nije daleka granica od dopuštenoga, a poticajno djeluje na mnoge političko-

[138] Ona se ipak „opravdava“ i iziskuje pri teškim kršenjima ljudskih prava, kao u jugoslavenskim ratovima, no to je još uvijek pravno prijeporno. 
vojne spekulante. „Nema sumnje da su procesi disolucije Jugoslavije makar počeli sa secesionističkim pokušajima nekih komponenata federacije." Ako je država nastala pristankom bivše, onda je riječ o disoluciji (Kohen, 2006, 2). Ti su pokreti u Jugoslaviji počeli i završili s Kosovom i o kojoj ćemo kratko razložiti.

Badinter je uzeo „AVNOJ-evske“ granice kao administrativne i buduće vanjske granice država, dok Radan tomu prigovara jer je te iste granice odredila totalitaristička i pobjednička vojna grupacija, a nisu određene narodnom voljom kao takvom. No, „narodnom voljom“ nije ni Hrvatska ušla u (prvu) jugoslavensku zajednicu niti je Sabor ikada ratificirao odluke Jugoslavenskoga odbora. Također, autor spekulira i oko samoga datuma disolucije koji je naveden u mišljenju arbitražne komisije. Pitanje je i tko je ravnopravan i konstitutivan u biti, države (federacije), narodi ili republike? ${ }^{[139]}$ Srpski se narod pozivao na konstitutivnost koju nasljeduje još od Države Srba, Hrvata i Slovenaca prije ujedinjenja s Kraljevinom Srbijom ${ }^{[140]}$, ali pitanje je može li jedan narod biti konstitutivan u više (novih) država. Načelno ne može, ali opet, prema BiH ili Švicarskoj, vidimo da to nije slučaj apsolutno gledajući. Državotvornost u smislu stvaranja nove države ipak se u teoriji (ali nepisano) zabranjuje onim narodima koji već imaju svoju „matičnu zemlju“ (Perišić, 2013, 768). No, manjine nemaju nužno matičnu državu (Baski, Romi), a i srpska bi manjina u novim državama, prema tome, imala pravo na državnost samo u slučaju da ne postoji „Republika Srbija“, što je dvolično. Jednako tako bi i hrvatski narod (ne samo manjina) mogao to tražiti u susjednoj BiH ili pak hrvatska manjina u Vojvodini i Austriji. Tako bi se to moglo primijeniti na Srbe i Hrvate ali, i Bošnjake u Sandžaku ili na etničke skupine u Vojvodini i Crnoj Gori. ${ }^{[141]}$ Međutim, pitanje je najdelikatnije bilo u slučaju albanskih Kosovara s obzirom na Albaniju. Tu se doskočilo pravilu o posebnom identitetu naroda koji kao kosovski albanski nije isti albanskom u Albaniji

\footnotetext{
$\overline{\text { [139] Tako i Hasani, 2003 }}, 207$ koji kaže da je uti possidetis juris nastao kao rezultat razvoja dvaju drugih principa: 1. samoodređenja i 2. neinterveniranja u unutarnje poslove druge države.

[140] U slučaju Slovenije etnička je homogenost izjednačila pitanje suverenosti republike i njezinoga naroda. Godine 1990. Srbija je nasuprot konfederalnom prijedlogu preuređenja Jugoslavije, kakav su dale Hrvatska i Slovenija, predložila federalni preustroj prema kojemu bi građani bili ti koji tvore suverenost i uživaju jednaka prava, a ne ni narodi ni kolektivni entiteti. Upravo u konfederalizaciji vidimo da je i HDZ, odnosno Franjo Tuđman, naslijedio „komunistički princip“ i u pravu na samoodređenje. Da su korijeni ideje o samoodređenju naroda povezani s lenjinističko-staljinističkim idejama, vidi i: Oklopčić et al., 2005, 10.

[141] Bošnjaci u Sandžaku i Srbi te ostali u Vojvodini tražili su prije svega samo unutarnje samoodređenje.
} 
i nema navodno pretenzije spajanju (v: Perišić, 2013, 773). No, to otvara odmah i relativiziranja kod drugih naroda i pitanja mijenja li se time narodima njihovo pravo na ,nacionalnost' koju i kakvu žele. I, žele li svi narodi to iskoristiti samo kao paravan za ujedinjenje s velikom maticom ili ne? Nadalje, „kako razlučiti ustanike, koji ciljaju na svrgavanje postojećeg režima, od naroda koji ima pravo na samoodređenje“ (Perišić, 2013, 701). ${ }^{[142]}$

Secesija naroda, prema Dugardu, ima opravdanja ako se ispuni 5 kumulativnih uvjeta - dva pozitivna i tri negativna: mora postojati etnička, vjerska i ostala skupina koja je odvojena od glavne i ima svoj posebni identitet, ona treba okupirati određeni dio teritorija na kojem čini većinu (ne piše demografski u kojem obliku), treba im biti uskraćena znakovita participacija u državnoj vlasti, treba biti širokih povreda njihovih fundamentalnih ljudskih prava i moraju iscrpiti sve razumne mogućnosti osiguranja vlastita poštovanja na drugi način (Šućur, 2014, 282). Ne bi bilo loše da se ta definicija uzme u obzir pri novim konvencijama. No, jednako tako, prema tome, značilo bi to da nereprezentativnost u državnim organima, koja ne bi povlačila za sobom povrede ljudskih prava, ne bi zbog nedostatka „unutarnjega“ samoodređenja vodila automatski do ,vanjskoga“ samoodređenja. Nastavit ćemo o nekim detaljima vezano za raspad SFRJ.

Na sjednici Vrhovne komande OS SFRJ u ožujku 1991. Borislav Jović je visokim tonom, među ostalim, upitao člana Predsjedništva SRH Stjepana Mesića je li ustavno to što se oboružavaju paravojne formacije i što su stavljeni na stranu svi savezni zakoni. On mu je na to odgovorio da se sjeti situacije na Kosovu i da je albanski narod također narod. No, iako albanski narod nije jedan od konstitutivnih naroda u Jugoslaviji, ipak je u toj pokrajini već srušen postojeći Ustav (Smerdel, Sokol, 2007) pa se na njega ne mogu pozivati oni koji su ga „prekrojili“ tako da su ukinuli pokrajinske samouprave definirane u njemu (zbog navodnih republičkih pokreta na Kosovu). U suprotnom bi vojska JNA bila svakako legalna do dana sukcesije (isteka moratorija) ili disolucije i čak priznanja. Ipak, unatoč odbojnosti teze, u Jugoslaviji, a poslije i u drugim republikama, bilo je elemenata građanskoga rata kojega na spomenutoj sjednici predviđaju i

[142] U kosovski Ustav je stavljena zabrana ujedinjavanja s ikim. Kao što je i u hrvatski Ustav vezano za republike koje bi činile neku „novu“ Jugoslaviju. Pitanje je zbog čijega je to sve utjecaja tako. 
spominju, jer je rat (za vlast) bio na području jedne federalne ili unitarne države i između građana koji su bili njezini državljani i činili je, bez obzira na to što je mogla biti riječ o različitim ili čak istim nacionalnostima unutar nje (Hrvatske i Bosne ili Jugoslavije). ${ }^{[143]} \mathrm{Tu}$ je dalje bitno pitanje i odnos ustavnoga i međunarodnoga prava.

Ustav Socijalističke Federativne Republike Jugoslavije iz 1974. ${ }^{[144]}$ već u osnovnim načelima deklarira pravo svakoga „naroda“ na samoopredjeljenje (ne i države) „do odcjepljenja“. Oružane su snage jedinstvene i nedjeljive... Služe za oslobodilačku borbu i obranu cjelovitosti SFRJ (VI), ali se moraju poštovati nacionalna suverenost i ravnopravnost (?)VII). Država se u čl. 1. opisuje (ipak) kao „zajednica dobrovoljno ujedinjenih naroda i njihovih socijalističkih republika!“. Kosovo je pak u „sastavu Srbije“. Republika se zasniva na suverenosti naroda. Članak 5. je ipak nedvosmislen: teritorij SFRJ je „jedinstven“ i sastavljen od republika i ne može se mijenjati bez pristanka republike/a. Tu dobro Radan (infra) primjećuje da je Badinter iz konteksta izvadio samo drugi i četvrti stavak, a ne i prvu i treću odredbu članka o jedinstvenosti granice i „teritorije“ Jugoslavije, iako ona ne kreira sama po sebi međunarodno pravo a i djeluje kontradiktorna. No Jugoslavija, prema mišljenju Komisije, više i „ne postoji“. Dužnost je građana da sudjeluju u „društvenoj samozaštiti“ (čl. 173.). O retroaktivnosti se u čl. 211. propisuje da je ona dopuštena ako je riječ o „općem interesu“, što bi bilo zanimljivo da tako stoji i u današnjem Ustavu, gdje je načelo zakonitosti dovedeno u pitanje pri naknadnom dodavanju odredbe o nezastarivosti ratnoga profiterstva. Nadalje, „pravo i dužnost“ je naroda i narodnosti Jugoslavije „da štite i brane nezavisnost, suverenitet, teritorijalnu cjelokupnost i (...) društveno uređenje“ (čl. 237. i 244.). Ne treba ipak napominjati da je slom komunizma, odnosno socijalizma bio produkt globalnoga pokreta u (istočnoj) Europi i da nijedan ustav nije „vječan“. Savezni su organi nadređeni (čl. 268.) i osiguravaju neovisnost i suverenost (čl. 281.), dok Skupština i Savezno vijeće odlučuju o promjenama granica te o ratu i miru (čl. 283., 285.)! Ustavni sud o suglasnosti odlučuje prema čl. 375., a čl. 270., s druge strane, podosta

[143] Poput i antagonizma HVO-a i HOS-a, abdićevaca i ArBiH, babićevaca i martićevaca itd. I Srbi u Hrvatskoj uvijek se nazivaju „pobunjenim Srbima u RH“. Ali to ipak nije u skladu s Karadžićevom tvrdnjom kako su se morali organizirati da ne bi ispalo da se „bune protiv vlastite države“. U svakom slučaju, za onoga za koga je neka akcija agresija za drugoga je oslobađanje i o terminima se politički spekulira, pri čemu se gubi njihova izvornost.

[144] Donesen 21.2. 1974 
eksplicitno ističe kako savezni zakoni vrijede na „cijelom“ teritoriju savezne države, a oni su svakako bili antiseparatistički.

Ustav Socijalističke Republike Hrvatske (dalje: SRH) ${ }^{[145]}$ u prvome članku osnovnih načela piše kako je hrvatski narod zajedno sa srpskim narodom u zajedničkoj borbi uspostavio državu SRH „na temelju prava na samoodređenje - uključujući i pravo na odcjepljenje i udruživanje s drugim republikama, svojom slobodnom voljom a radi zaštite svoje nacionalne neovisnosti... “. Tu on naciju definira kao zajedništvo dvaju „konstitutivnih“ naroda - Hrvata i Srba („bratskim jedinstvom“). U čl. VII. govori kako ljudi dosljedno provode politiku mira i svim raspoloživim sredstvima i oružanom borbom brane „svoju“ slobodu (ali) i „nezavisnost, suverenitet, teritorijalnu cjelokupnost... SRH kao i SFRJ“. SRH sudjeluje „ravnopravno“ s drugim republikama u organima vlasti i vanjskoj politici, a ona sama definirana je u čl. 1. gl. 1. kao „nacionalna država hrvatskoga naroda, država srpskog naroda u Hrvatskoj i država narodnosti koje u njoj žive“. Predmet je rasprave često bila tzv. konstitutivnost više naroda u Hrvatskoj. Nomotehničkim iščitavanjem riječ je ne samo o jednom ili dvama narodima nego o svim narodnostima u državi. ${ }^{[146]}$ No, teleološkom analizom ipak su dva „temeljna“ naroda jer i „Ustavni zakon“ tzv. Republike Srpske Krajine imao je istu formulaciju, no tako da je stavio srpski narod na prvo mjesto pa zatim sve „ostale“ narode. Treći i politički (a i pravni) diskurs tiče se pitanja posljedica koje ta odredba nosi. Sa srpske strane argumenti su bili u tome da to pravo sa sobom povlači odluku o zajedničkoj sudbini države i teritorija, i to podjednako od srpskoga naroda, kao i hrvatskoga. U krajnjoj konzekvenciji, ako ne bi bilo konsenzusa, država bi se trebala „podijeliti“. Također, umjesto „samo“ određenoga broja predstavnika manjinskih zajednica i njihovih klubova, u Saboru bi trebalo postojati i pravo saborskoga veta i tako dalje. Hrvatska strana nije o tome htjela niti raspravljati jer je, za razliku od delikatnije situacije $\mathrm{u} \mathrm{BiH}$, gdje je konstitutivnost triju naroda bila i ostala kao takva, novu Republiku Hrvatsku proglasila je kao zemlju jednoga temeljnog i brojčano najvećega naroda te ostalih nacionalnih manjina. Činjenica je da je nova država sljednica stare, ali ne treba imati i nema iste ustavne odredbe. Pogleda li se i

[145] NN, br. 8. od 22. 2. 1974, str. 110. nadalje.

[146] Zato su romski i židovski pripadnici tražili svoja zastupnička prava pred ESLJP-om. 
čl. 4. staroga Ustava SRH, u njemu stoji kako se granice SRH mogu mijenjati samo na osnovi odluke Sabora i „u skladu sa izraženom voljom stanovnika na koje se odnosi promjena“. Glede potonjega, nije jasno misli li se tu i na manjinu, odnosno većinu „stanovnika“ u onim (istočnim) dijelovima koji žele ili ne žele biti u granicama nove Hrvatske. To komplicirano pitanje, nasreću, i nije važno jer veznik „i“, a ne „ili“, sugerira da mora biti posrijedi kumulativno ispunjenje i jedne i druge pretpostavke za promjenu granica hrvatske republike: odluka Sabora i volja stanovnika. Ravnopravnost naroda jamči(la) se člankom 137. staroga Ustava, a „narodna obrana“ i samozaštita ipak se ostavljaju diskretno i (u) tijelima lokalne i mjesne samouprave (prema čl. 157., 169., 184.), kao i referendumska izjašnjavanja (čl. 126., 160.). Ali sve to ne smije biti protivno jedinstvenosti SRH (čl. 325.), zbog čega je i S. Mesić referendume u SAO Krajini nazvao protuustavnima. Problem je jedino što SRH više ne postoji zapravo. Sabor je međutim prema čl. 350. bio taj koji i raspisuje referendume i odlučuje o promjenama granica. Današnji Ustav ima sličnu potonju formulaciju, kao i spomenutu zabranu ikakvih akcija i prava koja potkopavaju ustavnopravni i jedinstveni suvereni poredak.

Najveća većina svjetskih i europskih ustava dalje zabranjuje bilo kakav secesionistički pokret i samoodređenje grupe koja ne čini vlast, kao i zadiranje u nepovredivost granica i teritorijalnu cjelovitost. Ali ima malih iznimki koje potvrđuju pravilo. Navedimo samo neke odredbe država ${ }^{[147]}$.

Albanija je parlamentarna republika, jedinstvena i nedjeljiva (čl. 1.). Suverenost Albanije pripada ljudima tj. narodu (u čl. 2.). Vojska jamči slobodu, integritet i ustavni poredak (čl. 12.). Također, Albanija vodi brigu o interesima albanskoga naroda u drugim državama (slično kao i Hrvatska o Hrvatima iz $\mathrm{BiH}$ ). Suverenost, jedinstvenost i neovisnost Andore zabilježene su u čl. 107. njezina ustava, a suverenost kao takvu također izvodi iz „naroda“. Armenski ustav govori slično i već na početku predviđa referendum kao oblik izravne demokracije i suverenosti naroda. Svi ustavi promiču ljudska prava i njihove dokumente. Predsjednik Armenije garantira cjelovitost, sigurnost i neovisnost države (čl. 49.). Svatko je dužan braniti republiku (čl. 47.). Vršenje sloboda i prava ne smije biti usmjereno prema rušenju ustavnoga poretka i promicanju 
nasilja, nesnošljivosti i rata (čl. 48.). Austrija je federalna država (čl. 1.), ali jedinstvene nacionalnosti (čl. 6.). Mauricius je suverena demokratska republika (čl. 1.) i dalje ne govori o narodu i jedinstvu, nego odmah prelazi na ljudska prava. Republika Kosovo je neovisna, suverena, demokratska, jedinstvena i nedjeljiva država (čl. 1.) i dalje se nastavlja opreznim „tonom“ kako je ona država svojih građana koji svoja ljudska prava i slobode mogu ostvarivati unutar granica, ali se isto tako propisuje kako republika ne samo da nema pretenzije nego se i NE želi ujediniti ni s jednom drugom državom (čl. 3.), misleći time prije svega na Srbiju i Albaniju. Državu predstavlja kao „multietničku“ sastavljenu od Albanaca i „drugih“ građana. Italija je pak „demokratska država utemeljena u radu“ (čl. 1.). Suverenost je narodna, a republika je nedjeljiva, ali prepoznaje lokalnu autonomiju i decentralizaciju (čl. 5.). Italija „čuva“ jezične manjine (čl. 6.), odbacuje rat $\mathrm{i}$ bilo kakvu agresiju prema slobodama ljudi, ali je zanimljivo da se i „odriče“ suverenosti onoliko koliko je to potrebno za svjetski mir i poredak te jednakost s drugim državama (čl. 11.). U 13. odjeljku prijelaznih odredaba zabranjeni su boravak i glasanje disidentima Kuće Savoj i potomcima kraljevske porodice. Referendum se jedino ne dopušta u vezi s porezom, proračunom, sklapanjem međunarodnih ugovora i sličnim. Lihtenštajn, kao monarhija na „demokratskim temeljima“, određuje da se granice mogu mijenjati samo zakonom, a one između komuna i unije mogu se mijenjati i većinskom odlukom građana na čiji se teritorij promjena odnosi (čl. 4. (1)). No, pojedine se komune mogu i secesirati istom odlukom (čl. 4. (2)), što je bitna liberalna razlika u usporedbi s drugim ustavima! Secesija se može regulirati zakonom ili ugovorom, nastavlja. U potonjem slučaju ponovno se provodi referendum. Člankom 7. belgijskoga Ustava predviđa se promjena granica samo u skladu sa „zakonom“. Granica između jezičnih regija može se mijenjati odlukom građana ili se neka provincija može staviti pod izravnu federalnu nadležnost ili u posebni status. A kralj se „kune čuvati teritorijalno jedinstvo i neovisnost“ (čl. 91.). Ukrajina je neovisna, unitarna i nedjeljiva država te nepromjenjivih granica i jednoga državljanstva (čl. 1.-4.). Secesija, odnosno promjena teritorija, moguća je čak, ali samo „sveukrajinskim“ referendumom (čl. 73.), dok je u drugim državama poput Hrvatske to prepušteno isključivo saboru. Isto tako sveukrajinski referendum teško da će imati senzibiliteta prema pojedinim graničnim 
pokrajinama. Republika Srpska definira u ustavu ${ }^{[148]}$ : „Republika Srpska je jedinstven i nedjeljiv ustavno-pravni entitet... Srbi, Bošnjaci i Hrvati, kao konstitutivni narodi, Ostali i građani, ravnopravno i bez diskriminacije učestvuju u vršenju vlasti u Republici Srpskoj... glavni grad je Sarajevo.“ Tako su predviđena i tri jezika.

U velikoj većini svjetskih, odnosno europskih ustava secesionistički su pokreti stoga ili zabranjeni izričito ili prešutno, dok su ondje gdje opstaju regulirani posebnim odredbama i vrlo malo ih je liberalno u vezi s tim pitanjem, što nameće zaključak da su secesije „protuustavne“ u modernom UN-ovu svjetskom državnom poretku, a pravo na samoodređenje malo koji ustav i spominje.

\section{Mišljenja Badinterove komisije; legalitet i legitimitet novih (jugoslavenskih) država}

Badinterova komisija, sastavljena od pet sudaca na čelu s predsjednikom Ustavnoga suda Francuske Robertom Badinterom, donosila je mnogo mišljenja u prve tri godine rata vezanih za krizu u Jugoslaviji i jugoslavenskim državama. ${ }^{[149]}$

Prvo mišljenje iz 1991. god. ${ }^{[150]}$ kaže da je Jugoslavija u „procesu disolucije“ i, prema Bečkim konvencijama iz 1978. i 1983., nove države ispunjavaju kriterije za svoju državnost, dok SFRJ prestaje postojati kao cijela jer su esencijalni organi vlade prestali funkcionirati. Sve su nove države sljednice bivše, a ne samo jedna (mišljenje 9 i 10). Priznanje je samo deklarativno.

Prema drugome mišljenju od 11. siječnja 1992. ${ }^{[151]}$, na pitanje ima li srpski narod u Hrvatskoj i Bosni i Hercegovini pravo na samoodređenje odgovoreno je kako pravo na samoodređenje nije dovoljno definirano $\mathrm{u}$ međunarodnome pravu, ali da nikako ne može utjecati na položaj granica (prema načelu uti possidetis). Spomenuti manjinski narodi u novim državama imaju i trebaju imati sva prava manjina.

\footnotetext{
[148] Dostupno na: http://www.narodnaskupstinars.net/sites/default/files/upload/dokumenti/ustav/lat/ustav_ republike_srpske.pdf (8/4/2017)

[149] Dostupno na: http://www.pf.uni-lj.si/media/skrk_mnenja.badinterjeve.arbitrazne.komisije.1_.10.pdf (10/4/2017.), uvod M. Ragazzi.

[150] Opinion No. 1 - I.L.M. Page 1494.

[151] Opinion No. 2 - I.L.M. Page 1497.
} 
Treće mišljenje ${ }^{[152]}$ - prema čl. 5 Ustava SFRJ i već rečenom - kaže da se granice republika ne mogu mijenjati bez dogovora.

Peter Radan iznio je kritičku analizu mišljenja komisije, koju možemo ukratko evocirati i vidjeti njezinu utemeljenost. (Radan, 2000) Prvom mišljenju prigovara zbog toga što se taj princip zapravo odnosi na secesiju, a podvodi se pod disoluciju. On smatra da spominjani osvrti kanadskoga Vrhovnoga suda u postupku protiv Quebeca govore o raspadu države, a ne o secesiji, iako taj sud izrijekom spominje i secesiju pod određenim uvjetima. No, prema kanadskome Ustavu, ona je također načelno zabranjena. Međutim, istina je i da je Ustavom iz 1974. bilo predviđeno samo „etničko samoodređenje do odcjepljenja“, a ne teritorijalno, te da nije bilo spominjano ništa o raspadu i primjeni načela uti possidetis ni kod jednoga slučaja. Samoodređenje naroda lako bi se moglo provesti samo na onim dijelovima teritorija na kojima narodi, koji se osamostaljuju, čine većinu. No činjenica je da pojam samoodređenja nije u međunarodnome pravu razložen u smislu koji je od dvaju (odnosno četiriju) modela samoodređenja pravno osnovaniji, a jednako tako ni većine i referendumi nisu postavljeni kao ikakvo mjerilo, a niti kao conditio sine qua non ${ }^{[153]}$, dok mnogi ustavi, vidjeli smo, preciznije predviđaju teritorije na koje se referendum odnosi i većine glasova ${ }^{[154]}$ koje moraju biti pozitivne da bi se prijedlog usvojio, ako se i smije. Radan smatra da etnički princip secesije ne mora nužno pratiti teritorijalni u provincijskim granicama i da postoji „značajna manjina“ koja želi ostati u državi od koje se odvaja. ${ }^{[155]}$ Nadalje, uz raspravu o točnome datumu disolucije, prigovara selektivnosti odabira argumenata, uključujući one iz čl. 5. Ustava SFRJ. Kolonijalni pak princip uti possidetisa ne želi preslikati na Srbiju čiji se narodi onda tobože „dekoloniziraju“. Tvrdi kako je pitanje novih granica među državama bilo političko, ali isto tako politički, više nego pravno, predlaže jedino rješenje problema, a to su referendumi u svim etničkim regijama i preseljenje stanovništva između jednih i drugih novih državnih područja (?). Radan podsjeća kako je još 1977. glavni tajnik OUA tvrdio kako načelo uti possidetis

[152] Opinion No. 3 - I.L.M. Page 1499.

[153] U međunarodnome pravu jednostrano proglašenje secesije zasnivano na popularnome glasovanju nije ništa legalnije od obrnutoga slučaja i ovisi samo o priznanju. Lindsay, 2016, 39 prema J.A. Crawfordu.

[154] Katkada čak i kvalificiranu većinu, što je upitno je li u skladu s općenitošću prava na samoodređenje jer smo i kod manjinskih prava vidjeli sličan problem s kriterijem brojčanosti.

[155] R. Karadžić: „Ako vi već želite izaći iz Jugoslavije, što vam ne branimo, ne možete onda prisiljavati i drugi narod koji želi ostati u njoj..." 
nije sveto načelo i kako se može izvrgnuti, napose na osnovi „prava na samoodređenje“. A jednako tako citira McCorquodalea koji naglašava ne samo razliku nego i suprotnost između tih dvaju pravnih pojmova i tako što smatra da je uti possidetis načelo koje vrijedi za vlade i očuvanje njihove suverenosti, a ne za interese „naroda“. Chipman se također slaže s tim da nove manjine ne treba ostavljati u državama u kojima mogu biti ugroženi njihovo dostojanstvo ili ljudska prava, no Hrvatska se, osim ustavnim zakonom, vezala i faktičnom obvezom zaštite tih prava koja "prate“ svjetske institucije i agencije (poput Amnesty Internationala). Ronald Rich veli pak da je „čudno“ da se pravilo dopuštanja „secesije“ u federalnim državama ne bi smjelo proširiti i na one unitarne. Što se tiče prestanka funkcioniranja saveznih organa u Jugoslaviji, koji čine njezinu efektivnu opstojnost, ipak zaključujemo kako bi manjak reprezentativnosti u federalnim organima značio da bi svatko tko bi svojevoljno napustio mjesto (kao npr. na 14., izvanrednom Kongresu SKJ) uzrokovao raspad države, iz kojih god razloga. Jednako tako bi i situacija u $\mathrm{BiH}$ nalikovala na raspad države, premda je, za razliku od SFR Jugoslavije, bilo donekle zabranjeno razmatrati bilo kakvu opciju raspada $\mathrm{BiH}$ (ili Federacije $\mathrm{BiH}) .^{[156]}$

Poput Petera Radana i Brad Roth kritizira Badinterovo mišljenje te uopće pojam razdruživanja, odnosno stanja ili procesa disolucije koji, prema njemu, također nema temelja u međunarodnome pravu, nego je rezultat ad hoc autoritetnoga mišljenja. On ide pak dotle da ni narodima Jugoslavije ne pridaje pravo na samoodređenje uopće („prema međunarodnom pravu“) i sve nalaze Badinterove komisije podvodi pod „šire političke namjere“ i pokušaj stabiliziranja situacije za koji je upitno je li uopće ostvaren uspješno. ${ }^{[157]}$ Buchanan u svojim radovima odbija apriornu legitimnost administrativnih granica u slučajevima samoodređenja, a ne samo što podsjeća na distinkciju između ovih dvaju pojmova i pojava (Buchanan, 1997, 300). ${ }^{[158]}$ Prvi bi (uti possidetis), prema Oklopčiću, trebao biti izvan rasprave i o teritorijalnim pravima i pravu na samoodređenje. Pravni „odlazak“ iz jedne države mogao bi biti i „veća patnja“ nego ostanak u njoj,

[156] Abdić (u početku potpredsjednik SDA) za HRT: Izetbegović će morati odustati od nerealne ideje jedinstvenosti „bivše“ BiH. Cjepkanje te priznate države bilo je zabranjeno ipak još i Rezolucijom 787 kao i 1031 VS-a UN-a.

[157] Radan tvrdi da je Badinterov princip inzistiranja na administrativnim granicama „katastrofalan“ $i$ da je mogao biti jednakoga učinka, a manje „bolan“ da je primijenjeno dobrovoljno (?) preseljenje iz regije u regiju. Ovako je homogenost Hrvatske i heterogenost BiH koja je de facto podijeljena zapravo jedini rezultat toga pristupa.

[158] Isti pisac tvrdi kako je u „godinama secesije“ trenutačno međunarodno okruženje manje ugroženo konfliktima među državama koliko rušenjem pravnih poredaka unutar država. 
tvrdi Šućur 2014 (282). ${ }^{[159]}$

Erika Harris u Političkoj misli propituje zašto u međunarodnome pravu vlada normativna konfuzija i je li samoodređenje naroda uopće „pravo“ ili tek „politička aspiracija“ i tko je točno na njega legitimiran. Narodi imaju „pravo“ na samoodređenje prema postojećim međunarodnim izvorima, ali je, vidimo, pitanje je li to pravo još uvijek „pozitivno pravo“ i koji je njegov sadržaj.

U Hrvatskoj (napose u hrvatskoj javnosti) vlada percepcija „bezgrešnog začeća državnosti“[160], što ne znači da je istina suprotna, ali je svakako multiperspektivna glede međunarodnoga i interdisiplinarnoga prava i politologije. Ovaj se rad ne bavi pitanjem zločina, no, iako je politika vezana za sve to, zadatak je upravo znanosti kritički i slobodoumno raspravljati i postavljati pitanja o tome. ${ }^{[161]}$ Opća je tvrdnja koja se može čuti da je Hrvatska nastala - na Domovinskome ratu. To bi a contrario značilo da nije nastala na „pravu“ i da se, u slučaju da nije vojno pobijedila, uistinu ne bi imala pravo nazivati državom i postojati. Ironija je i u pitanju bi li Hrvatska (ili barem hrvatski narod) imala i moralno pravo na državnost i političko samoodređenje da, ne samo da nije uspjela u ratu nego da, odredba o odcjepljenju naroda nije bila igrom slučaja implementirana u Ustav SFRJ iz 1974. koji je najčešće citiran (Oklopčić, 2015, 8.). Pravni argument, bio on ili ne bio opinio juris, uglavnom „služi državnicima više samo kao ukras“ a „secesionistički pokreti vole pravne argumente kada su im dostupni ili naklonjeni, iako o njima, u krajnjoj liniji, ne ovise“ (Oklopčić, 2015, 9). U slučaju jugoslavenskih republika još je najveća apstrakcija to što se pravo na samoodređenje naroda de facto izjednačilo, a u referendumima implicitno i podrazumijevalo s teritorijalnim obuhvaćanjem granica SRH kao vanjskih granica RH.

Politički-pravno gledajući, ono što ide u prilog novih državnosti ipak su plebisciti i međusobno priznavanje republika koje su zajedno činile većinu u bivšoj Jugoslaviji te jugoslavenska nemogućnost da zadrži

\footnotetext{
[159] No, prema Pelletu (1992), malo je moguće vjerovati da bi pravnici uopće mogli utjecati na politički tijek zbivanja i uglavnom planirani rat.

[160] Vidjeti: Oklopčić, 2015, 7. „Neki politički projekti... mogu s vremenom dobiti opravdanje i legitimnost, koji su im možda na početku nedostajali.“ Ibid., 14.

[161] Đurđević, 2016, Predgovor „Zagrebačkoj pravnoj reviji“, sv. 5, br. 3.

Oklopčić u predgovoru Političke misli za 2015. ide dotle da čak mnijenje o „bezgrešnoj legitimnosti“ izvire iz „samoizabranog neznanja“ te da se nijedna ozbiljnija rasprava od samostalnosti nije bavila tim pitanjem.
} 
saveznu vlast i da održi postojanje saveznih organa. ${ }^{[162]}$ Glavno je pitanje i zašto se htjelo uopće težiti tomu da se Jugoslavija cijela raspadne, jer da se samo jedan njezin dio ili jedna republika pokušala odcijepiti, tada bi to bila secesija. Odgovor je da „secesija“ zvuči „protupravnije“, a zapravo je samoodređenje ponajviše povezano upravo s njom i ona kao takva ipak nije „zabranjena“ u međunarodnome pravu, što je potvrdio i Međunarodni sud „pravde“ u slučaju Kosova. ${ }^{[163]}$ No, izbjegava se odgovor na to je li ona, sukladno tomu i - dopuštena, odnosno u kojim uvjetima i s kojim reperkusijama. ${ }^{[164]}{ }^{[165]}$ Politički predstavnici UN-a su povijesno odbijali i spominjanje, a kamoli legalizaciju secesije (Eastwood Jr., 1993). „Države“ ne bi ipak smjele ovisiti o kvalifikaciji i raspletu federacija kao disolucije ili secesije. Presumpcija i inercija je uvijek prvotno protiv razbijanja bilo kakvih unitarnih pa i federalnih država te su mnogi pokušaji propali a da se o njihovoj moralnopravnoj legitimnosti nije mnogo raspravljalo (poput Biafre, Katange, Južnoga Sudana u Africi ili Bangladeša). Pobijedio je „teritorijalni princip“, ali tako da tu uopće nije ni argumentiran kao ključan. Prema Oppenheimu, raspad države slučaj je kada država na cijelome svojem teritoriju prestane postojati i od nje nastanu dvije ili više država, što je na kraju i bilo (Radan, 2002, 206). ${ }^{[166]}$

[162] Vidjeti slično i Radan, 2002, 205.

[163] „Jednostrana deklaracija o nezavisnosti nije a priori protivna međunarodnom pravu“, što kosovski slučaj čini opiniom juris erga omnes. Znači li znači onda da je i dopuštena? Vidi: Perišić, 2013, 774 i Rez. 1244.

Nakon Kosova, Krim je najbrža izvedena secesija u modernoj povijesti, iako je de iure još uvijek priznat kao dio Ukrajine (a mnogi dugotrajniji entiteti nisu dobili prepoznatost). Time pada u vodu efektivnost vremena kakva se iziskivala od kanadskoga Vrhovnog suda koji je raspravljao o statusu i postupanju Quebeca. Ni Kosovo nije dobilo prepoznatost devedesetih, a 2008. se „odustalo od svih diplomatskih napora“ koji bi bili kontraproduktivniji od secesije. I danas se Srbiji implicitno ili eksplicitno nameće priznanje Kosova kao interesni uvjet za ulazak u EU. Iako se postavlja pitanje zašto se to nije učinilo potkraj 80-ih ili 90-ih godina 20. st., kada je ugroza na Kosovu bila najveća. Nesumnjivo je tu i zapadni interes bio protivan Ustavu Srbije i Jugoslavije, a nesigurno je da li je bio i protivan međunarodnomu pravu. Uzima se da je Kosovo „specijalan“ slučaj, a ne tako i za druge pokrajine. To je bio dosad najrizičniji potez Saveznika koji je, prema nekima, mogao uzrokovati i treći svjetski rat. Jer otvaranjem Pandorine kutije priliku bi, osim pokrajina, moglo dobiti 6000 etničkih skupina, kako tvrdi Christakis. Dodik se poziva na primjer Kosova za osamostaljenje RS, a centralizaciju kakvu spočitava Bošnjacima provela je upravo Srbija na Kosovu, iako je, osim jakoga većinskoga stanovništva, ono imalo i administrativne granice (za razliku od npr. „Republike Srpske Krajine“). [164] U slučaju odcjepljenja Quebeca od Kanade, kanadski je Vrhovni sud konstatirao kako je u određenim situacijama i okolnostima moguća secesija. Secession of Quebec Supreme Court of Canada od 20.08.1998., ILM 37 (1998), par. 1373 .

[165] Dok se secesija ipak gleda većinom kao ultima ratio, uti possidetis je katkada teleološki nespojiv i sa secesijom zbog toga što su same administrativne granice, npr. poput granica Quebeca, dane u mnogo većem opsegu od onih koje bi inače bile. U Jugoslaviji su granice također bile i veće i manje nego povijesne ili one do kojih je moglo doći aneksijom, odnosno debelacijom pobjedničkih saveznika (i ispunjavanjem uvjeta Londonskih i inih ugovora). Da su administrativne granice integrativni, a ne dezintegrativni čimbenik, slaže se i Ratner. Istina je da svaki oblik decentralizacije (bilo federalnih bilo homogenih država) kad-tad potencijalno vodi prema secesiji a ne samo miru. A prema spomenutom autoru nijedan od državotvoraca federalnih država nije imao na umu da će administrativne granice biti buduće međunarodne (Tito), ali i to da su te granice autoritarno određene bez konzultiranja sa svim stranama. No, takve konzultacije u prvoj Jugoslaviji vodile su prema beskrajnim reorganizacijama banovina, a KPJ je ipak odredila „srednje varijante“ od „velikih“ država.

[166] Inače bi i SAD u građanskome ratu bio u procesu „raspada“, što je de facto i bio, ali ne de iure. I Jugoslaviju kao 
U slučaju pak „SRJ“, njezin Ustav u preambuli ističe „neprekidnu (pravnu) kontinuiranost“ Jugoslavije, a poslije naglašava da su se Republika Srbija i Republika Crna Gora odlučile ujediniti (iako je potonja u svojemu prvom referendumu bila „za“ ostanak u - SFRJ a Bulatović čak glasao za cjelovitost republika). U novoj zajednici zadržano je (samo) ime Jugoslavije. U čl. 3. govori se o granicama među (novim) članicama i prema van. Savezna je vlada opet nadređena, a, dok Ustav govori o manjinama, o samoodređenju se više uopće ne govori. Što bi, prema prošlom i tom ustavu, bilo da je Srbija bila ta koja se htjela osamostaliti prema istim principima?

Memorandum SANU iz 1986., uz mnoge druge, naglasio je navodnu srpsku podređenost na Kosovu, a ne obrnut slučaj. On je još naglašavao genocid prema Srbima, a upravo „srpske akcije u Hrvatskoj i BiH odražavale su više sličnosti s nacistima nego obrnuto" (Hasani, 2003, 227). ${ }^{[167]}$ Hadžić tako govori o RS. Hannum (1993) piše kako su srpski i hrvatski nacionalisti u BiH i srpski u Hrvatskoj provodili etnička čišćenja pod paravanom prava na samoodređenje. Radanov je pristup drukčiji jer ne propagira „nasilan“, nego „dobrovoljan“ premještaj stanovništva, no vidjeli smo da je „humano preseljenje " također zapravo etničko čišćenje, jer tko bi samovoljno otišao iz svojega doma i posjeda? Genocid kao i etničko čišćenje uzima se kao jedan razlog zbog kojega je secesija opravdana i nužna. No, postavljeno je pitanje može li sama opasnost od genocida (kakvu su „propagirali“ Srbi) biti casus secessionis. Jasno je da bi to bilo ipak preekstenzivno tumačenje kada čak i sam genocid u određenim slučajevima („plemenskih“ građanskih ratova) ne bi bio valjan razlog za podjelu zemlje kao u Ruandi.

Ono što najviše ide u prilog konceptu rješavanja jugoslavenskih i budućih inih pitanja jest tendencija koja je ipak vidljiva u pitanju oko granice između Burkine Faso i Malija, gdje je Medunarodni sud prepoznao prividnu suprotnost između prava na samoodređenje i uti possidetisa, ali je opet sve to sveo na svrhu stabilnosti u prihvaćanju statusa quo kakav su mnoge (afričke) države prihvatile upravo u dobroj volji. Sud je načelo uti possidetis proglasio općim načelom koje se ne odnosi samo na jedan specifični međunarodnopravni odnos, nego na način sprječavanja bratoubojičke borbe. Svakako je toj borbi na Balkanu pridonio i odnos

jedinstvenu u početku su preferirale sve sile.

[167] Prema Cohenovu Serbia's secret war. 
većih interesnih sila. No, time nije dokazao da je to uvijek tako bolje i da će se popustiti, niti je sud konkluzirao o problemu prava na samoodređenje naroda kada je ono neovisno o upravnim kontekstima, odnosno kada ni administrativnih ni bilo ikakvih granica uopće nema. ${ }^{[168]}$

\section{Zaključak}

Iako je uti possidetis dio običajnoga prava (Kohen, 2006, 14), prigovara mu se njegovo poopćivanje na slučajeve modernih federacija, kao i pravna snaga Badinterova opinio juris. Badinter je ipak bilo savjetodavno i neobvezujuće mišljenje unutar EZ-a vezano za jugoslavensku krizu. (Hasani, 2003, 56.) Da bi nešto postalo uopće međunarodni običaj kao izvor međunarodnoga prava, treba biti oživotvoreno kroz prepoznatu praksu, a jednako tako tu praksu treba pratiti i pravna svijest, odnosno opinio juris. ${ }^{[169]}$ Nije, međutim, isključeno da će se upravo ovakvim presedanima, ako se nastave primjenjivati na buduće slučajeve, otvoriti put legitimnom međunarodnom običaju. Najveći je zadatak pravne i političke volje da se prije bilo kakve rasprave pravo na samoodređenje naroda, kao jedno od najosjetljivijih i najzloupotrebljavanijih prava, pozitivnije odredi, nedvosmisleno pa čak i kazuistički ili takstativno (za koga, prema kome, gdje i kada). ${ }^{[170]}$ Ovakvom općenitošću norme uvodi se pravna nesigurnost i možda gore stanje nego prije. No, unatoč tomu, zbog političkih razloga i odnosa svjetskih sila ne možemo očekivati brzo rješenje, ali možemo lako zaključiti da je ipak međunarodni normativizam svakim nešto detaljnijim izlaganjem pokazao da je njegova namjera restriktivno i općenito tumačiti to pravo u svjetlu odnosa prema (danas već fiktivnim) vanjskim okupatorima, a ne proširivati državotvorne i secesionističke pokrete u svijetu, dok se radi raznih političkih želja pojam samoodređenja naroda ne samo ekstenzivno nego licemjerno i selektivno te pejorativno tumači, ovisno o tome o kojim je teritorijima i interesima riječ u svijetu. „Oba prava naroda organiziranih u državu, na slobodu od vanjske dominacije i pravo naroda države na vlast koja odražava njihove želje, esencijalne su komponente prava na

[168] Frontier Dispute case paras. 20-26. ICJ Haag od 22. 12. 1986. dostupno na: http://www.icj-cij.org/docket/index. php? sum $=359 \& p 1=3 \&$ p2 $=3 \&$ case $=69 \& p 3=5(11 / 4 / 2017)$

[169] Članak 38.(1)(b) Statuta Međunarodnog suda „pravde“ u Haagu (ICJ)

[170] S takvim pristupom donekle se ne slaže Eastwood jer smatra da je najbolje rješenje tražiti u postojećem pravilo o pravu na samoodređenje, a ne stvaranje novog. 
samoodređenje." ${ }^{[171]}$ Raspadi Jugoslavije i Sovjetskoga Saveza, prema Hannumu, nisu mnogo učinili u razumijevanju prava na samoodređenje koje je i dalje inkluzivno, a ne ekskluzivno i separatističko pravo (prof. Franck). Dosljednim provođenjem prava na samoodređenje „svih“ ljudi otišlo bi se pak u besmisao i anarhiju jer bi to pravo išlo logički do svakoga „bloka kuća“ i ne samo gradova, enklava i ulica, nego i do pojedinih kuća i „kućnih savjeta“ ili do zadnjih osoba u njima koje bi mogle tražiti svoje „slobode“.[172] [173]

\section{Literatura}

ARAUJO, R., 2001, Sovereignty, Human rights, and SelfDetermination: The meaning of International Law, Fordham International Law Journal, 24(1), 1477-1532.

BERLIN, I., 1958, Two Concepts of Liberty, Oxford Clarendon Press.

Biblija, 2005, Knjiga Postanka 12, 2-7., Kršćanska sadašnjost, Zagreb.

BUCHANAN, A., 1997, Self-Determination, Secession, and the Rule of Law. The Morality of Nationalism, 301-320.

CASSESE, A., 1996, Self-Determination of Peoples..., Cambridge, UK.

CHRISTAKIS, T., 2015, Self-Determination, Territorial Integrity and Fait Accompli in the Case of Crimea, ZaöRV 75(1), 75-100. Dostupno na: http://www.zaoerv.de/75_2015/75_2015_1_a_75_100.pdf (12/4/2017)

ĐURĐEVIĆ, Z., 2016, Predgovor Zagrebačkoj pravnoj reviji, sv. 5, br. 3 .

EASTWOOD JR., L. S., 1993, Secession: State Practice and International Law After The Dissolution of The Soviet Union and Yugoslavia, Duke Journal of Comparative \& International Law, 3(1), 299-

[171] Jugoslavenska je kriza bila one time only reaction a jednako tako pojam samoodređenja u postkolonijalnom je razdoblju navodno samo krinka iza koje se države koje su nedemokratske i diskriminirajuće kriju kako bi sačuvale svoju „suverenost“. Hannum, 1993, 33, 68.

[172] Nepraktičnost je, s jedne strane, inzistirati na homogenim državama, a, s druge strane, svaka secesionirana većina ostavlja u sebi manjinu koja više nema mogućnosti odvajati se: Eastwood Jr., 1993, 337 kao i Lee C. Buchheit. [173] Danas imamo mnoštvo secesionističkih pokreta ili stranaka, u gotovo svakoj državi (Felmišani i Valonci, pa i neki Istrijani, HR-HB, Moravljani, Alanđani, Bretonci, Savojci, Sicilijanci, Venecija, Normadi, Lombardi, Sj. Kosovo i ostali mnogi nabrojeni... Neki se žele i ujediniti kao npr. Islanđani s Norvežanima) itd. 
349.

FERNANDEZ JANKOV, F., ĆORIĆ, V. The legality of Uti Possidetis in the definition of Kosovo's legal status. Dostupno na: http://www.esil-sedi. eu/fichiers/fr/Agora_Fernandez_879.pdf (11/4/2017)

Glavni radovi Marxa i Engelsa, 1978, prir. DRAGIČEVIĆ, A., MIKECIN, V., NIKIĆ. M., Stvarnost, Zagreb.

HADŽIĆ, H., 2015, Ostvarivanje prava na secesiju putem primjene principa Uti possidetis iuris i principa prava na samoopredjeljenje naroda, Pravne tem, 3(5), 68-86.

HALL, W.E., 1890, A Treatise on International Law, Oxfford Press third ed.

HANNUM, H., 1993, Rethinking Self-Determination, Virginia Journal of International Law, 34(1), 1-69.

HASANI, E., 2003, Self-Determination, Territorial Integrity and International Stability: The Case of Yugoslavia, NDA, Beč.

MOORE, J.B., 1913, Costa Rica - Panama Arbitration, Memorandum on Uti Possidetis, The Commonwealth Co. Printers, Rosslyn U.S.A.

JACOBSEN, G. A., LIPMAN, M. H., 1946, Political Science, Barnes\&Noble, New York.

KOHEN, M. G., 2006, Secession, International Law Perspectives, Cambridge.

LAUTERPACHT, H., 1947, Recognition in International Law, Cambridge University Press.

LEROTIĆ, Z., 1977, Nacija, Kulturni Radnik, Zagreb.

LINDSAY, J. K., 2016, The Hollow Threat of Secession in Bosnia \& Herzegovina, LSEE - Research on South Eastern Europe (1), 1-53.

MANNHEIM, K., 1960, Man and Society In an Age of Reconstruction, L. Humphries, London.

MARSHALL, P. BROWN, 1921, The Aaland Island Question, The American Journal of International Law, 15(2), 268-272.

MARX, K., ENGELS, F., 1967, Radovi, izd. Naprijed, Zagreb.

OKLOPČIĆ, Z., 2015, Samoodređenje i odcjepljenje: slučaj Jugoslavije. Politička misao 52(1), 7-14.

PARSONS, T., 1967, Sociological Theory and Modern Society, Free Press California. 
PATTEN, A., 2015, Self-Determination for National Minorities, dostupno na: https://www.princeton.edu/ apatten/Self-Determination\%20 for\%20National\%20Minorities\%20-\%20Alan\%20Patten.pdf (11/4/2017)

PAŽANIN, A., 1973, Filozofija i politika, Fakultet političkih nauka, Zagreb.

PELLET, A., 1992, The Opinions of the Badinter Arbitration Committee A Second Breath for the Self-Determination of Peoples, EJIL (3), 178-185.

PERIŠIĆ, P., 2013, Pravo naroda na vanjsko samoodređenje izvan kolonijalnog konteksta i slučaj proglašenja nezavisnosti Kosova, Zbornik Pravnog fakulteta u Rijeci, 34(2), 761-783.

PHILLIPSON, C., 1916, Wheaton's elements of International Law, Stevens and Sons, London.

PROTEGA, M., 2016, Politička prava i slobode na političkim područjima u Prvoj Jugoslaviji u razdoblju od 1929.-1941., Pravnik, 100(1), 133-149.

RADAN, P., 2000, Post-Secession International Borders: A Critical Analysis of the Opinions of the Badinter Arbitration Comission, Melbourne University Law Review 3, 24(1), 50.

RADAN, P., 2002, The Break-up of Yugoslavia and International Law, Routledge London \& New York.

RATNER, S. R., 1996, Drawing a Better Line: Uti Possidetis and the Borders of New States, American Journal of International Law 90, 590-625.

SOLTAU, R. H., 1951, An Introduction to Politics, Longmans, USA.

RONEN, D., 1979, The Quest for Self-Determination, Yale Univ. Press.

Slobodna Dalmacija od 31. 12. 1991.

SMERDEL B., SOKOL, S., 2007, Ustavno pravo, Pravni fakultet Sveučilišta u Zagrebu, Zagreb.

SPAJIĆ, H., 2005, Protektorat u međunarodnom pravu, Pravnik, 39, 2(80), Zagreb.

ŠUĆUR, A., 2014, Observing the Questions of Self-Determination and Secession in the Wake of Recent Events in Kosovo, Abhazia, South Ossetia and Crimea, Zbornik Pravnog fakulteta u Rijeci 3(3), 275-301.

The Concise Oxford Dictionary of Current English, 1964, fifth ed. by 
Fowler.

VAJDA, M., NAMAČINSKI, M., 2015, Zločin protiv čovječnosti kao izraz državne politike, Godišnjak Akademije pravnih znanosti, 7(1), 142-184.

VOLKMANN-SCHLUCK, K-H., 1974, Politička filozofija - Tukidid Kant Tocqueville, prev., Šarinić Naprijed, Zagreb.

VRBAN, D., 2003, Država i pravo, Golden Marketing, Zagreb.

Zbornik radova, 1973, Razvoj i perspektive Ujedinjenih naroda, Fakultet političkih nauka Sveučilišta u Zagrebu, Zagreb.

Mrežne stranice, presude i propisi

Američka konvencija o ljudskim pravima dostupna na: http://www. oas.org/dil/treaties_b-32_american_convention_on_human_rights.pdf $(9 / 4 / 2017)$

Bečka deklaracija i program djelovanja, usvojena na Svjetskoj konferenciji o ljudskim pravima 14.-25. lipnja 1993. na 48. zasjedanju OUN-a rezolucija 48/121.

Centre for human rights 1987, UN sales No. E.87.XIV.2.

Deklaracija o davanju nezavisnosti kolonijalnim zemljama i narodima Rezolucija Opće skupštine 2621. (XXV) od 12. 10. 1970.

Deklaracija o načelima međunarodnoga prava o prijateljskim odnosima i suradnji između država u skladu s Poveljom UN-a iz 1970; Rezolucija 2625 OSUN.

Deklaracija o pravima osoba koje pripadaju nacionalnim ili etničkim, vjerskim i jezičnim manjinama; Rezolucija 47/135 OSUN od 18. veljače 1992. dostupna na http://www.un.org/documents/ga/res/47/ a47r135.htm (7/4/2017)

Europska konvencija i Afrička povelja o ljudskim pravima iz 1981. dostupna na: http://www.humanrights.se/wp-content/uploads/2012/01/ African-Charter-on-Human-and-Peoples-Rights.pdf (9/4/2017)

Europski ustavi na: www.constituteproject.org (8/4/2017)

Frontier Dispute case Burkina Faso vs. Mali paras. 20-26. ICJ Haag od 22. 12. 1986. dostupno na: http://www.icj-cij.org/docket/index. php?sum $=359 \& p 1=3 \& p 2=3 \&$ case $=69 \& p 3=5(11 / 4 / 2017)$ 
Islamska deklaracaija dostupna na: http://www.vakat.me/wpcontent/uploads/2017/01/Islamska-Deklaracija-knjiga-o-islamizacijimuslimana-Alija-Izetbegovic.pdf (8/4/2017)

Međunarodna konvencija o eliminaciji svih oblika rasne diskriminacije

Međunarodni pakt o građanskim i političkim pravima usvojen na Općoj skupštini Ujedinjenih naroda 16.12.1966. rezolucija br. 2200 A/XXI.

Memorandum SANU od 1986.

Mišljenja Badinterove komisije; Dostupno na: http://www.pf.unilj.si/media/skrk_mnenja.badinterjeve.arbitrazne.komisije.1_.10.pdf (10/4/2016), uvod M. Ragazzi.

Povelja UN stupila na snagu 1945. dostupna na: http://www.mvep. hr/CustomPages/Static/HRV/Files/ugovori/povelja_un_hr.pdf (12/4/2017)

Referendumi u BIH dosupni na: http://www.sudd.ch/event. php?lang=en\&id=ba011993 (10/4/2017)

Referendumska pitanja od NN 25. 4. 1991. dostupna na www. wikipedia.org (9/4/2017)

Rezolucija 787 i 1031 VS UN.

Rezolucija br. 41/128 OSUN od 4.12.1986. i Rezolucija 637 (VII) Dostupna na: www.nationalunitygovernment.org>pdf-doc (10/4/2017)

Rimski statut 1998.

Secession of Quebec Supreme Court of Canada od 20.08.1998., ILM 37 (1998)

Statut Međunarodnog suda "pravde“ u Haagu (ICJ).

UNESCO-va Deklaracija o temeljnim načelima doprinosa sredstava javnog priopćavanja učvršćenju mira te Memorandum UNESCO-a iz 1949.

Ustav Republike Srpske Dostupno na: http://www. narodnaskupstinars.net/sites/default/files/upload/dokumenti/ustav/lat/ ustav_republike_srpske.pdf (8/4/2017)

Ustav Socijalističke Federativne Republike Jugoslavije iz 1974. Donesen 21. 2. 1974. i dostupan na wikipedia.org (8/4/2017)

Ustav Socijalističke Republike Hrvatske NN br. 8. od 22. 2. 1974., str. 110. dalje.

Ustavni zakon o pravima nacionalnih manjina NN, 93/11.

Zakon o zaštiti prava i sloboda nacionalnih manjina („'Sl. list SRJ“, 
br. 11/2002, „Sl. list SCG“, br. 1/2003 - Ustavna povelja i „Sl. glasnik RS“, br. 72/2009 - dr. zakon i 97/2013 - odluka US-a.)

Završni akt konferencije u Helsinkiju dostupan na: www.osce.org/ helsinki-final-act?download=true (8/4/2017)

\section{Il diritto di autodeterminazione dei popoli nel contesto internazionale e della dissoluzione della Repubblica Socialista Federale di Jugoslavia}

Il diritto di autodeterminazione dei popoli è uno dei termini più discussi del diritto internazionale pubblico. Inoltre, questo termine non è soltanto giuridico, ma anche filosofico, politico, sociologico e lega a sé varie polemiche e ripercussioni. È per questo che l'approccio all'analisi del termine dev'essere dettagliato, graduale ed interdisciplinare affinché si possano osservare i vari aspetti del termine che portano alla risposta del quesito se l'autodeterminazione nazionale è un principio o un diritto e relativo a chi, se è un diritto jus cogens de facto e de iure o se è condizionato e limitato da altre norme del diritto internazionale contemporaneo. Qui si parla in primis del divieto cogente di lesione dell'integrità territoriale e della pace internazionale e della stabilità proclamati persino nella Dichiarazione delle Nazioni Unite. Il tutto suppone l'osservazione del principio uti possidetis, delle sue radici e dell'obbligo d'implementazione, come anche della secessione, conseguenza più frequente della realizzazione affermativa del diritto di autodeterminazione dei popoli. Inoltre, ciò è relativo al fenomeno della dissoluzione degli stati, soprattutto federali, per i quali è doveroso analizzare la presenza di distinzioni materiali riguardanti la secessione, la quale di per sé non è esplicitamente né opzionale né vietata. Lautore interpreta i relativi fenomeni e termini per mezzo del caso a noi più vicino e più familiare, la dissoluzione dell'ex Jugoslavia, la quale è stata un precedente moderno per gli stati federali, e che ha ripercussioni anche nei casi attuali dell'Ucraina e della Catalonia in Spagna. Con lo scopo di cristalizzare il legame fra il diritto, la politica e i vari interessi, si parla anche della costitutività dei popoli, delle minoranze e dei loro diritti in base ai molti documenti e alle opinioni degli analitici, ed infine 
della creazione e del riconoscimento di uno stato, per i quali nemmeno prevale un consenso se si tratta di un atto costituente o declaratorio da parte di terzi e della comunità internazionale. Al fine di evitare degli esiti catastrofici, ossia l'interiorizzazione dello "status quo" a livello giuridico, è opportuno discutere in maniera aperta per precisare la problematica legislativa ed evidenziare gli interessi contrari allo spirito delle Nazione Unite o semplicemente giustificatamente opposti.

Parole chiave: il diritto di autodeterminazione dei popoli, la dissoluzione della RSFJ, uti possidetis e la secessione, filosofia politica

\section{The Right to Self-determination in the Light of International Legal Issues and the Dissolution of Yugoslavia}

The right to self-determination of peoples is one of the most controversial concepts in public international law. Also, this concept is not only legal, but also philosophical, and also pertains to political science, sociology and entails various issues and repercussions. Therefore, its analysis should be approached in detail, gradually and with an interdisciplinary approach in order to comprehend the various important aspects of the concept that leads toward the answer to the following question - Is the selfdetermination of peoples a principle or a right and what else in involved here? Is this right jus cogens de facto and de jure or is it conditioned by the organic other rules of contemporary international order? This primarily refers to the cogent ban of breaching the territorial integrity of existing states and jeopardizing international peace and stability as proclaimed in the Charter of the United Nations. This entails a consideration of the principle of uti possidetis and its roots, as well as secession, the most common consequence of the affirmative exercising of the right to self-determination of peoples. Also on the continuation and dissolution of states, mostly federal, which is necessary for an analysis whether or not there are any material differences in relation to secession, which is also neither permitted nor prohibited. The author here will interpret our closest known case (one still recent) the breakup of the former Yugoslavia, which was a modern precedent for a federal state and has reverberation in current events like those in the Ukraine. In order to have a more complete impression of law, 
policy and various interests will also make mention of the constitutionality of peoples, minorities and their rights through a variety of documents and the opinions of scholars and also concepts concerning the nation and state recognition. There is no consensus whether it is a constitutive or declaratory act by third countries and the international community. In order to avoid a worst case scenario, the acceptance of the legal "status quo", it should be openly debated in order to avoid political and public diversions or distractions that hide interests which are either contrary to the spirit of the United Nations or, on the other hand, legitimately opposed to each other.

Key words: the right to self-determination of people, the dissolution of Yugoslavia, uti possidetis, secession, political philosophy 